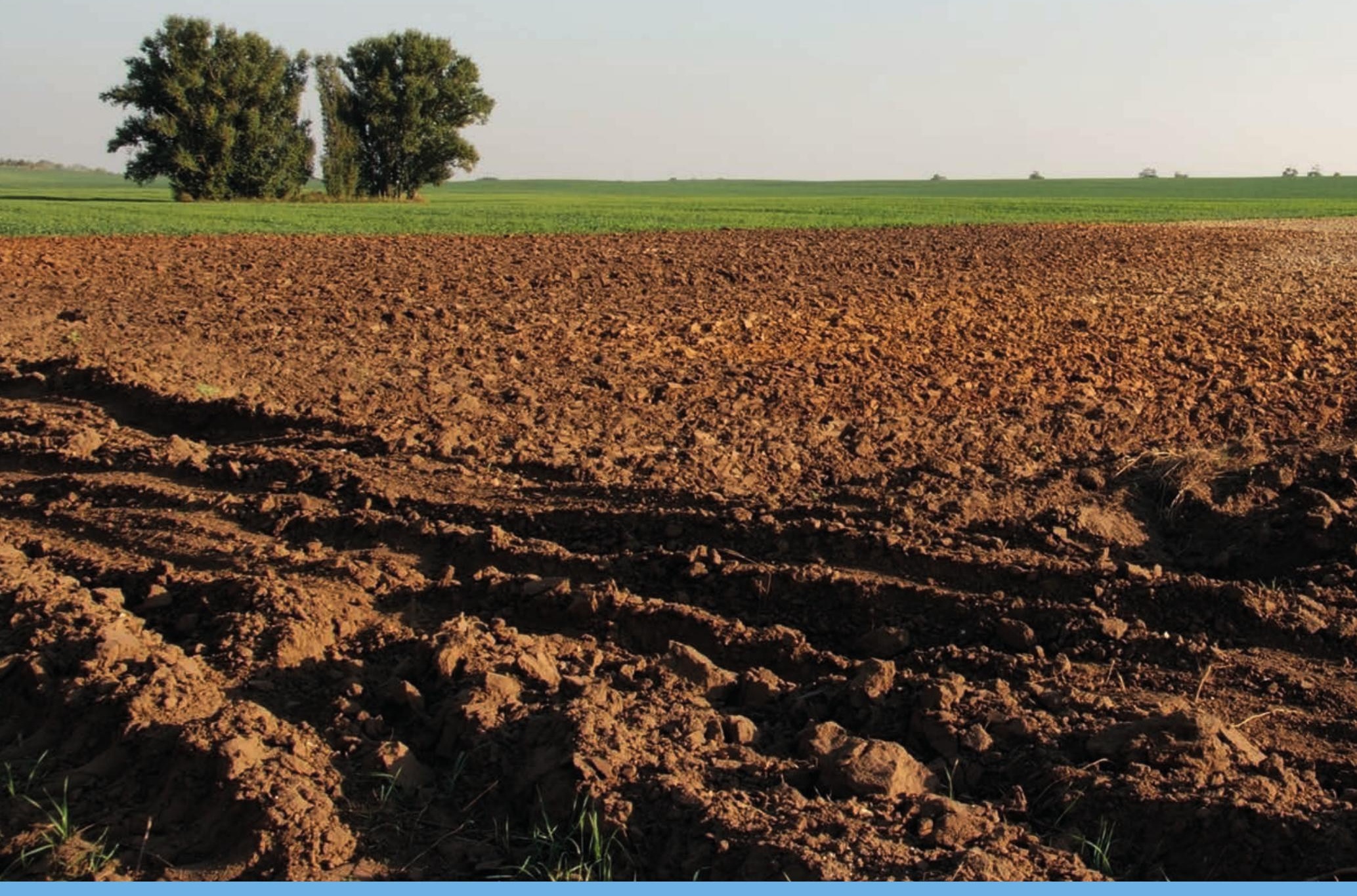

\title{
Rapportage werkzaamheden kennissysteem Beheer-op-Maat 2019
}





\section{Rapportage werkzaamheden kennissysteem Beheer-op-Maat 2019}

Tim Visser, Dick Melman, Igor Staritsky

Dit onderzoek is uitgevoerd door Wageningen Environmental Research in opdracht van en gefinancierd door het ministerie van Landbouw, Natuur en Voedselkwaliteit, in het kader van het Beleidsondersteunend onderzoekthema 'lerend beheer voor rendement ANLb' (BO-11-020-008).

Wageningen Environmental Research

Wageningen, juni 2020

Gereviewd door:

Onno Roosenschoon, onderzoeker (Wageningen Environmental Research)

Akkoord voor publicatie:

Marion Kluivers-Poodt, teamleider van team dierecologie (Wageningen

Environmental Research)

Rapport 3012

ISSN 1566-7197 
Visser, T., Th.C.P. Melman en I. Staritsky, 2020. Rapportage werkzaamheden kennissysteem Beheerop-Maat 2019. Wageningen, Wageningen Environmental Research, Rapport 3012. 42 blz.; 12 fig.; 2 tab.; 66 ref.

Het kennissysteem voor Agrarisch Natuurbeheer, Beheer-op-Maat (BoM), is in 2019 op een aantal aspecten aangepast aan de wensen van de gebruikers (beheercollectieven). De kaartlagen die aan de basis staan van het kennissysteem - de openheid van het landschap, de bodemvochtigheid, de aanwezigheid van verstorende bronnen en de zwaarte van het gewas - zijn geactualiseerd en/of verfijnd. Daarnaast is de kentallenanalyse toegevoegd. De kentallenanalyse geeft voor een werkgebied naar keuze de belangrijkste kentallen omtrent de effectiviteit van het weidevogelbeheer weer. De kentallen worden daarbij gepresenteerd in de vorm van figuren, met als doel in één oogopslag inzicht te geven in de knelpunten en verbetermogelijkheden omtrent het weidevogelbeheer in een specifiek gebied.

De gebruikersvriendelijkheid van het systeem is verbeterd door de gebruikersaccounts te koppelen aan gebiedsbegrenzingen zoals die worden toegepast in de boerenlandvogelmonitor van LandschappenNL. Ten slotte zijn belangrijke stappen gezet voor de uitbreiding van het kennissysteem naar de overige leefgebiedtypen: open akkers, droge dooradering en natte dooradering.

Trefwoorden: Beheer-op-Maat, Agrarisch natuurbeheer, collectieven, weidevogels, kennissysteem

Dit rapport is gratis te downloaden van https://doi.org/10.18174/523280 of op www.wur.nl/environmental-research (ga naar 'Wageningen Environmental Research' in de grijze balk onderaan). Wageningen Environmental Research verstrekt geen gedrukte exemplaren van rapporten.

2020 Wageningen Environmental Research (instituut binnen de rechtspersoon Stichting Wageningen Research), Postbus 47, 6700 AA Wageningen, T 03174807 00, www.wur.nl/environmental-research. Wageningen Environmental Research is onderdeel van Wageningen University \& Research.

- Overname, verveelvoudiging of openbaarmaking van deze uitgave is toegestaan mits met duidelijke bronvermelding.

- Overname, verveelvoudiging of openbaarmaking is niet toegestaan voor commerciële doeleinden en/of geldelijk gewin.

- Overname, verveelvoudiging of openbaarmaking is niet toegestaan voor die gedeelten van deze uitgave waarvan duidelijk is dat de auteursrechten liggen bij derden en/of zijn voorbehouden.

Wageningen Environmental Research aanvaardt geen aansprakelijkheid voor eventuele schade voortvloeiend uit het gebruik van de resultaten van dit onderzoek of de toepassing van de adviezen.

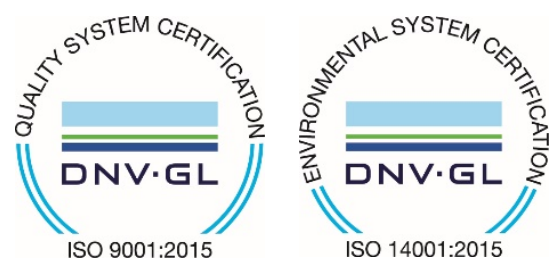

Wageningen Environmental Research werkt sinds 2003 met een ISO 9001 gecertificeerd kwaliteitsmanagementsysteem. In 2006 heeft Wageningen Environmental Research een milieuzorgsysteem geïmplementeerd, gecertificeerd volgens de norm ISO 14001.

Wageningen Environmental Research geeft via ISO 26000 invulling aan haar maatschappelijke verantwoordelijkheid.

Wageningen Environmental Research Rapport 3012 | ISSN 1566-7197 


\section{Inhoud}

$\begin{array}{ll}\text { Verantwoording } & 5\end{array}$

$\begin{array}{ll}\text { Samenvatting } & 7\end{array}$

$\begin{array}{lr}1 & 11\end{array}$

2 Doelstellingen $r$

$\begin{array}{llr}3 & \text { Resultaten } & 13\end{array}$

3.1 Kentallenanalyse $\quad 13$

3.2 Uitbreiding BoM naar andere leefgebiedtypen 16

3.3 Applicatiebeheer BoM-weidevogels $\quad 22$

3.3.1 Verfijning losse factoren $\quad 22$

$\begin{array}{ll}\text { 3.3.2 Update begrenzingen } & 27\end{array}$

3.3.3 Vernieuwde toepassingen satellietbeelden 28

$\begin{array}{lll}3.4 & \text { Communicatie } & 33\end{array}$

$\begin{array}{llr}4 & \text { Discussie } & 35\end{array}$

$5 \quad$ Conclusies en aanbevelingen $\quad 37$

$\begin{array}{ll}\text { Literatuur } & \mathbf{3 8}\end{array}$ 



\section{Verantwoording}

Rapport: 3012

Projectnummer: 5200045074

Wageningen Environmental Research (WENR) hecht grote waarde aan de kwaliteit van zijn eindproducten. Een review van de rapporten op wetenschappelijke kwaliteit door een referent maakt standaard onderdeel uit van ons kwaliteitsbeleid.

Akkoord Referent die het rapport heeft beoordeeld,

functie: Onderzoeker

naam: Onno Roosenschoon

datum: Juni 2020

Akkoord teamleider voor de inhoud,

naam: Marion Kluivers-Poodt

datum: Juni 2020 


\section{Samenvatting}

De beheerregimes in het agrarisch natuurbeheer worden van tijd tot tijd aangepast. Dit wordt gedaan naar aanleiding van praktijkervaringen en nieuwe inzichten uit onderzoek. Het geheel kan worden aangeduid als lerend beheer: doen - leren - beter doen. Goede, laagdrempelige ontsluiting van wetenschappelijke kennis is hier cruciaal. Door het toegankelijk maken en delen van wetenschappelijke kennis over soorten, gebieden en beheermaatregelen in combinatie met praktijkervaring, kan lerend beheren vorm krijgen en verder worden ontwikkeld.

In dit kader is de afgelopen jaren gewerkt aan Beheer-op-Maat (BoM), het kennissysteem voor agrarisch natuurbeheer dat wetenschappelijke kennis met betrekking tot weidevogels op een laagdrempelige manier ontsluit. Met dit kennissysteem kunnen beheerders zelfstandig analyses uitvoeren voor hun eigen werkgebieden. Deze analyses hebben betrekking op een groot aantal aspecten (landschappelijke kwaliteit, ligging beheer, aanbod kuikenland, etc.) die tezamen inzicht geven in de verwachte habitatkwaliteit en daarmee de verwachte effectiviteit van het gevoerde beheer. De resultaten van de analyses vormen vervolgens voeding voor het proces van planoptimalisatie. Het achterliggende doel van Beheer-op-Maat is de ecologische effectiviteit van het gevoerde beheer te maximaliseren. BoM probeert bij te dragen aan het ontwikkelen van één taal en één begrippenset binnen het agrarisch natuurbeheer. Daarmee worden kwaliteiten van verschillende gebieden en de inzet van het beheer met elkaar vergelijkbaar (benchmarking) en kunnen op basis daarvan kennis en ervaringen onderling worden uitgewisseld en kan er worden geleerd.

In dit project is op verschillende punten verder gewerkt aan het kennissysteem. Het betreft de volgende onderdelen:

- Uitbreiding gebruikersfaciliteiten (uitbreiding analysemogelijkheden);

- Uitbreiding naar andere leefgebiedtypen, naast open grasland of open akker en droge dooradering;

- Kalibratie van de groenindex (NDVI) wat betreft samenhang met graslandtype en preferentie daarvoor van een aantal weidevogelsoorten;

- Technisch applicatiebeheer.

\section{Resultaten}

\section{Toevoeging kentallenanalyse}

De kentallenanalyse geeft voor een werkgebied de belangrijkste kentallen omtrent de habitatkwaliteit voor weidevogels en het daaraan gelieerde beheer. De kentallen worden gepresenteerd in de vorm van figuren, met als doel in één oogopslag inzicht te geven in de knelpunten en verbetermogelijkheden omtrent het weidevogelbeheer in een specifiek gebied.

Uitbreiding naar andere leefgebiedtypen

Voor een aantal gidssoorten (o.a. Patrijs en Grauwe kiekendief) is een habitatkwaliteitssystematiek ontwikkeld, waarmee kaarten kunnen worden gemaakt die de habitatkwaliteit weergeven. In een vervolgproject kunnen dergelijke concepten operationeel worden gemaakt.

Binnen BoM-weidevogels is voorts een aantal kaartlagen geactualiseerd en verfijnd (openheid, bodemvochtigheid, verstoring en zwaarte gewas). Hierdoor is de bruikbaarheid voor de praktijk sterk toegenomen. Er is een nieuwe set aan gebiedsbegrenzingen toegevoegd die overeenkomt met de BTStelgebieden die LandschappenNL hanteert. Daarmee kunnen voor deze, voor de beheerders relevante, gebieden evaluaties worden gedaan.

Voor de NDVI-beelden is een bescheiden kalibratie uitgevoerd. Deze laat zien dat er een duidelijke samenhang is tussen NDVI en graslandtype en dat de weidevogeldichtheid hiermee sterk samenhangt. NDVI en habitatkwaliteit hangen daarmee aantoonbaar samen. Hiermee komen nieuwe, interessante 
toepassingsmogelijkheden voor NDVI in zicht, namelijk het vaststellen van habitatkwaliteit, los van het ter plekke heersende beheerregime.

\section{Applicatiebeheer}

De kaartlagen die aan de basis staan van het kennissysteem - de openheid van het landschap, de bodemvochtigheid, de aanwezigheid van verstorende bronnen en de zwaarte van het gewas - zijn geactualiseerd en/of verfijnd:

- Bodemvochtigheid: In het verleden was de bodemvochtigheidskaart uitsluitend gebaseerd op de drooglegging. Voor de nieuwe kaart vormt de drooglegging nog steeds de basis. De kaart is nu echter gedifferentieerd naar het bodemtype, waarbij rekening wordt gehouden met het vochthoudend vermogen van de verschillende bodemtypen. Daarnaast is rekening gehouden met kwel en wegzijging.

- Aanwezigheid verstorende bronnen: De kaart met betrekking tot de aanwezigheid van verstorende elementen is vernieuwd. In de vorige versie was een cel wel of niet verstoord. In de vernieuwde versie wordt gewerkt met gradaties van verstoring. Daarbij wordt rekening gehouden met 1 ) het feit dat de verstorende werking afneemt naarmate de afstand ten opzichte van de bron toeneemt, 2) het feit dat het verstorende effect afhankelijk is van de soort en 3) het feit dat de mate van verstoring afhankelijk is van de bron van verstoring.

- Openheid landschap \& zwaarte gewas: Beide kaartbeelden zijn geactualiseerd.

\section{Gebiedsbegrenzingen voor uitvoeren analyses.}

Voor het uitvoeren van berekeningen is het noodzakelijk het gebied te bepalen waarop deze berekeningen van toepassing zijn. De begrenzing van de te kiezen gebieden moet relevant zijn voor de beheerders en als ecologische, ruimtelijke eenheid. Daarvoor lijken de gebieden zoals die in de Boerenlandmonitor van LandschappenNL worden onderscheiden het geschiktst. Deze begrenzingenzijn door LandschappenNL ter beschikking gesteld en opgenomen in BoM, waarbij ze zijn gekoppeld aan de gebruikersaccounts.

\section{Overleg met potentiële gebruikers}

Met verschillende gebruikersgroepen is contact geweest, waarvan de belangrijkste zijn: de collectieven/BoerenNatuur, de weidevogelcoördinatoren van LandschappenNL en provincies. Tijdens deze overleggen zijn ontwikkelingen en wensen besproken. Wat betreft de gebruikerswensen zijn afspraken gemaakt en deels gerealiseerd. Dit betreft bijvoorbeeld het onderscheiden van logische gebiedseenheden voor planvorming en -evaluatie en de wijze waarop de zogenaamde weidevogelstippen uit externe databases kunnen worden ingeladen in het kennissysteem voor analyse en evaluatie.

Dergelijke overleggen zijn bepalend voor het genereren van draagvlak voor BoM en stimuleren het gebruik ervan. Omdat het aantal wensen de mogelijkheden van realisatie verre overstijgt, is het belangrijk om gezamenlijk, met ontwikkelaars van het kennissysteem en de gebruikers, tot een fasering en prioritering te komen. Daarvoor is het wenselijk om tot een gebruikersgroep te komen die een afspiegeling is van het geheel aan gebruikers (bijvoorbeeld vertegenwoordiging vanuit alle leefgebiedtypen). In overleg met BoerenNatuur en LandschappenNL kan hieraan in een vervolg aandacht worden geschonken.

\section{Conclusie}

Dit project stond in het teken van het onderhoud aan BoM en het verder aanpassen om zowel wetenschappelijk als ICT-technisch up-to-date te zijn. Verder was het van belang om zo goed mogelijk op de wensen van gebruikers aan te sluiten. Dit is een voortdurend proces en is allesbehalve afgerond met dit project. Voor weidevogels is het systeem inhoudelijk en qua gebruikersvriendelijkheid voorlopig functioneel en is de tijd rijp om het systeem in de praktijk volop te gebruiken om kritisch te kijken naar de landschappelijke kenmerken in het eigen gebied en naar de lokalisatie, omvang en aard (zwaarte) van de beheerinspanningen. De bevindingen in eigen gebied kunnen worden vergeleken met die in andere gebieden, zodat systematisch kan worden vormgegeven aan lerend beheer.

Voor de andere leefgebiedtypen staat het kennissysteem pas aan het begin. Voor een aantal gidssoorten zijn de habitatseisen en bottleneckfactoren geïdentificeerd en waar mogelijk gekwantificeerd en is het concept uitgewerkt hoe het in BoM zou kunnen worden opgenomen. Het 
relateren van beheermaatregelen (type, areaal) aan habitatkwaliteit is in veel gevallen weerbarstiger dan voor open grasland. Ook is er sprake van hiaten in de ecologische kennis van de doelsoorten. Ondanks deze onvolkomenheden, of misschien wel dankzij, is het werken aan het kennissysteem belangrijk. Immers, van de collectieven wordt verwacht dat zij met hun beheeractiviteiten bijdragen aan versterking van de populaties van de doelsoorten. Dus waar het aan dergelijke kennis ontbreekt, moet gewerkt worden aan het vergaren daarvan. Het verder ontwikkelen van het kennissysteem kan daarmee een belangrijke impuls geven aan nieuw onderzoek. 


\section{$1 \quad$ Inleiding}

Voor een effectief agrarisch natuurbeheer is goede ontsluiting van kennis cruciaal. Door het toegankelijk maken en delen van kennis over soorten, gebieden, beheermaatregelen kan het lerend beheer vorm krijgen en verder ontwikkeld worden. In voorgaande jaren is er gewerkt aan het kennissysteem agrarisch natuurbeheer Beheer-op-Maat (BoM). Dat ontsluit beschikbare, ecologisch relevante informatie op een voor beheerders laagdrempelige wijze. Het accent ligt tot nu toe op het weidevogelbeheer.

Waar het weidevogels betreft, is BoM inhoudelijk al redelijk ver ontwikkeld. Het is belangrijk om te weten of het voor de praktijk van de collectieven ook kan werken. Essentieel bij het verder ontwikkelen van BoM is zicht te hebben op de ervaringen van de gebruikers en hun (verbeter)wensen. Daartoe is samenwerking gezocht met BoerenNatuur (BN) en Hogeschool Van Hall Larenstein (HVHL). Daar bleek belangstelling voor te zijn. De ex-ante-evaluatie ANLb-2016, waarin de beheerplannen van de collectieven op ligging, ruimtelijke samenhang en kwaliteit zijn geëvalueerd (Melman et al., 2016), was voor de collectieven aanleiding om de inzet van het beheer te verbeteren.

Door HVHL en BNL is in 2017 en 2018 het initiatief genomen om een aantal werkplaatsen te organiseren gericht op de verbetering van de weidevogelbeheerplannen. Daarbij wilden ze graag gebruikmaken van BoM. Dat paste precies bij de scope van onderhavig project. In deze werkplaatsen stond lerend beheren centraal en deze bijeenkomsten hadden tevens het doel om bij te dragen aan het werken aan één taal en begrippenset voor het weidevogelbeheer, waaraan door alle betrokkenen een groot belang wordt toegekend. De bijeenkomsten leverden inzicht in de toegankelijkheid en bruikbaarheid van BoM en boden tevens de gelegenheid om verbeterwensen te inventariseren (Manhoudt et al., 2018).

De opbrengst van de werkplaatsen in 2017 en 2018 was de voeding voor de werkzaamheden zoals die in onderhavig project zijn opgepakt en uitgevoerd.

Het kennissysteem agrarisch natuurbeheer in het kort (voor een overzicht van de rapportages, zie literatuur)

Het kennissysteem ontsluit ecologische kennis voor de leefgebiedtypen die in het ANB relevant zijn. Het is opgenomen in een GIS. Het omvat:

- Kennisregels voor bepaling basis habitatkwaliteit (geïntegreerde beoordeling van diverse habitatfactoren);

- Kennisregels voor bepaling gerealiseerde habitatkwaliteit door beheer (geïntegreerde beoordeling basis habitatkwaliteit + beheerregime);

- Indicatoren voor succesvolle territoria (geïntegreerde beoordeling gerealiseerde habitatkwaliteit en aanwezige territoria);

- Koppelingsmogelijkheden met externe bronnen voor beheer (bv. RVO-bestanden) en soortverspreidingskaarten (bijvoorbeeld SOVON, De Landschappen);

- Mogelijkheden voor toevoegen van eigen gegevens over beheer en voorkomen van soorten

- Kansrijkdomkaarten (gebaseerd op verspreiding soorten en gebiedseigenschappen) [alsmede kaarten van de begrensde gebieden, zodat zichtbaar is waar van spanning tussen beide sprake is];

- Soorten fiches (identiek aan die van www.portaalnatuurenlandschap).

PM (wel conceptueel ontwikkeld, nog niet in het systeem opgenomen):

- Indicatoren voor ruimtelijke concentratie van beheer per leefgebiedtype;

- Indicatoren voor ruimtelijke samenhang tussen beheer verschillende leefgebiedtypen.

Het kennissysteem kan gebieden karakteriseren in de vorm van kentallen, onder andere: omvang, basishabitatkwaliteit, areaal verschillende beheervormen, gerealiseerde habitatkwaliteit, dichtheid territoria, door beheer veiliggestelde territoria, etc.

Het kennissysteem is online ontsloten en biedt voor collectieven de mogelijkheid om bovenstaande zaken voor het eigen gebied uit te zoeken. 


\section{Doelstellingen}

Het kennissysteem Beheer-op-Maat heeft als doel alle beschikbare, relevante wetenschappelijke kennis omtrent weidevogelbeheer te vertalen naar kaartbeelden en figuren die eenvoudig te interpreteren zijn. Binnen Beheer-op-Maat kan de gebruiker analyses uitvoeren voor het eigen werkgebied (o.a. landschappelijke kwaliteit, ligging en effectiviteit van het beheer). De uitkomsten van de analyses vormen vervolgens input voor planverbetering. Het uiteindelijke doel is dat BoM een betrouwbaar en erkend hulpmiddel is om de ecologische effectiviteit van het beheer te vergroten.

Achterliggend doel van dit project is de bruikbaarheid van het kennissysteem voor lerend beheer in het agrarisch natuurbeheer te vergroten. De door HVHL georganiseerde werkplaatsen (zowel in 2017 als 2018) boden daarvoor belangrijke input, als bron van gebruikerservaringen en verbeterwensen. De doelstellingen voor 2019 zijn gebaseerd op de verbeterpunten die zijn aangedragen door de collectieven, zowel tijdens de werkplaatsen als na gebruik van het kennissysteem voor planoptimalisatie.

De doelstellingen voor 2019 zijn:

1. Operationaliseren kentallenanalyse

Vorig jaar is een concept ontwikkeld voor een kentallenanalyse, met de belangrijkste kentallen omtrent de inzet en effectiviteit van weidevogelbeheer. Doel is om de kentallenanalyse in 2019 operationeel te maken. Gebruikers van BoM dienen met één druk op de knop de kentallenanalyse te kunnen uitdraaien voor een deelgebied naar keuze.

2. Uitbreiding naar andere leefgebiedtypen

Nu het kennissysteem voor het weidevogelbeheer vorm heeft gekregen en zijn weg naar de praktijk vindt, is het gewenst ook aan de andere leefgebiedtypen aandacht te besteden (open akkers, droge dooradering en natte dooradering/water). Hiertoe is in 2018 is een stappenplan gemaakt. Het doel is om dit stappenplan in 2019 uit te voeren. Als eerste dienen de leefgebiedtypen open akker en droge dooradering te worden opgepakt.

3. Applicatiebeheer

Gebruik van BoM maakt voortdurende aandacht voor de technische aspecten van BoM noodzakelijk. Het gaat zowel om applicatiebeheer in technische zin (bv. oplossen bugs; actualiseren informatie) als om het realiseren van kleine aanpassingen die belemmeringen in het gebruik wegnemen.

4. Communicatie

Via overleg, mail, telefoon e.d. zal contact worden gehouden met Boerennatuur, collectieven e.d. Dit zowel bij het maken van keuzes op hoofdlijnen (m.n. met Boerennatuur) als over technische aspecten en gebruikerswensen (collectieven). Waar nodig zal contact worden gezocht met organisaties als LandschappenNL, Sovon en andere gegevens-leverende organisaties. Gedurende het jaar zullen gebruikers m.b.v. nieuwsbrieven en/of presentaties op de hoogte worden gehouden van vernieuwingen en uitbreidingen in BoM. Vanuit het project zal worden geparticipeerd in relevante overleggen rond kennisontsluiting t.b.v. agrarisch natuurbeheer.

5. Gebruikersgroep

Het afgelopen jaar is duidelijk geworden dat verbeteringen aan het kennissysteem naar aanleiding van verbeterwensen van gebruikers tot veel enthousiasme leiden. Om verbeterwensen in de toekomst op een meer systematische manier in beeld te krijgen, lijkt het raadzaam om een gebruikersgroep samen te stellen die met enige regelmaat bijeenkomt om de ontwikkeling van het kennissysteem te bespreken. De verbeterwensen die binnen deze gebruikersgroep naar voren komen, zouden sturend kunnen zijn voor doorontwikkeling van het kennissysteem. 


\subsection{Kentallenanalyse}

\section{Samenstellen kentallenanalyse}

Kentallen geven de belangrijkste informatie omtrent weidevogelbeheer op een kernachtige en overzichtelijke wijze weer (in figuren en tabellen) voor een bepaald (deel)gebied. De kentallen hebben betrekking op gebiedseigenschappen, beheerinspanningen en aantallen/dichtheden van de weidevogels. De kentallen kunnen helpen bij het analyseren van gebiedseigenschappen en de effectiviteit van het gevoerde weidevogelbeheer en kunnen een belangrijke rol innemen binnen het proces van planoptimalisatie. Ze maken het ook mogelijk om gebieden onderling te vergelijken (benchmark) en geven een houvast om van elkaar te leren. Tijdens de werkplaatsen in januari 2018 is in overleg met de collectieven verkend welke kentallen onderdeel zouden moeten zijn van een dergelijke analyse. Met de geleverde input is gekomen tot onderstaand resultaat (zie Figuur 1). Met behulp van de kentallenanalyse verkrijgt de beheerder/het collectief inzicht in:

1. Beheer1

Aantal hectare per beheerpakket, binnen geselecteerd deelgebied, op basis van recentst aangeleverde beheermozaïek.

2. Weidevogels

Aantallen, dichtheid en BTS: ontwikkelingen weidevogelpopulatie per soort (aantallen, dichtheden en bruto territoriaal succes). Maak gebruik van de selectieknop 'Jaar' om te kiezen voor een specifiek broedseizoen of voor het langjarig gemiddelde.

3. Potentiële kwaliteit

De potentiële kwaliteit is de combinatie van drooglegging, openheid, verstoring en de voedselrijkdom van de bodem. In het geval dat alle vier de factoren op orde zijn, wordt een hoge potentiële kwaliteit toegeschreven aan de locatie in kwestie. Wanneer een of meerdere factoren niet optimaal zijn, neemt de potentiële kwaliteit van de locatie af. Binnen dit cirkeldiagram is weergegeven hoeveel hectare van het deelgebied behoort tot de vier kwaliteitscategorieën. Met behulp van de selectieknop 'beheerd/onbeheerd' kan worden gekozen of de potentiële kwaliteit van het gehele gebied of alleen van het beheerde/onbeheerde deel van het gebied wordt weergegeven.

4. Overzicht knelpunten t.a.v. potentiële kwaliteit

In deze figuur is te zien welk van de vier kritische factoren (drooglegging, openheid, verstoring, productiviteit) de grootste problemen oplevert ten aanzien van de basiskwaliteit van het gebied.

5. Verdeling beheer over potentiële kwaliteit

Deze figuur geeft weer of de beheerpakketten op de juiste locaties liggen. De binnenste ring geeft de potentiële kwaliteit van het gebied in klassen weer (en komt dus overeen met Figuur 3). De buitenste ring geeft weer hoeveel hectare beheer er is gelegen op/binnen iedere kwaliteitscategorie. Daarmee kan deze figuur antwoord geven op de volgende vragen:

- Ligt het zware beheer op de correcte locaties (gebieden met een hoge/redelijke 'potentiële kwaliteit') of is het gelegen op locaties die eigenlijk minder geschikt zijn (locaties met een zeer lage/lage potentiële kwaliteit)?

- Zijn er gemiste kansen (locaties die een hoge/redelijke potentiële kwaliteit hebben waarop geen/licht beheer wordt uitgevoerd)?

6. Gerealiseerde kwaliteit

De gerealiseerde kwaliteit is de combinatie van de basiskwaliteit en het toegewezen beheer. Een hoge potentiële kwaliteit resulteert niet altijd in een hoge gerealiseerde kwaliteit. Uitsluitend wanneer de juiste (zware) beheerpakketten aan locaties met een hoge potentiële kwaliteit worden toegeschreven, wordt een hoge gerealiseerde kwaliteit bereikt (het beheer is uiteindelijk de bepalende factor). Binnen deze cirkeldiagram is weergegeven hoeveel hectare van het deelgebied behoort tot de vier kwaliteitscategorieën. Met behulp van de selectieknop 'beheerd/onbeheerd' kan

\footnotetext{
${ }^{1}$ De nummering van de kentallen komt terug in de nummers van de onderdelen van Figuur 1.
} 
worden gekozen of de gerealiseerde kwaliteit van het gehele gebied of alleen van het beheerde/onbeheerde deel van het gebied wordt weergegeven.

\section{Operationalisering Kentallen}

De kentallenanalyse is in 2019 geoperationaliseerd en kan nu op gebiedsniveau worden berekend. Voor de begrenzing van de gebieden is gebruikgemaakt van de BTS-begrenzingen, beschikbaar gesteld door LandschappenNL. Om te voorkomen dat lang moet worden gewacht op de resultaten van de analyse, is ervoor gekozen om alle analyses van tevoren te berekenen in de offlineomgeving van het kennissysteem. De resultaten van deze analyses kunnen via de website - na inloggen - voor het eigen werkgebied worden gedownload in de vorm van een pdf-bestand. De analyseresultaten zijn beschikbaar in het format zoals weergegeven in Figuur 1.

Vanuit technisch oogpunt is een groot aantal stappen doorlopen om de kentallenanalyse automatisch te kunnen berekenen. Op hoofdlijnen betreft dit de volgende aanpak:

- Met behulp van Geografische Informatie Systemen (GIS) zijn de losse habitatfactoren en gegevens m.b.t. weidevogelterritoria en beheer met elkaar gecombineerd. De gegevens zijn vervolgens geëxporteerd in de vorm van 'comma seperated value files (csv)', ten behoeve van de rekensnelheid. Ook is een aantal vertaaltabellen, bijvoorbeeld die de beheercode omzetten in een type beheer ('zwaar', 'licht', 'geen'), als csv beschikbaar gemaakt.

- In de programmeertaal Python 3 is een programma geschreven dat - op basis van de gereedgemaakte invoerbestanden - pdf-bestanden met kentallenanalyse per deelgebied kan maken. Voor de ontwikkeling is gebruikgemaakt van Jupyter notebook (Python 3) en de 'Pandas'- en 'Matlibplot'-bibliotheken.

- Het script kan in Jupyter notebook of direct in een Python 3-omgeving gedraaid worden.

Mogelijke verbeterpunten dienen in de toekomst besproken te worden met de gebruikersgroep. 


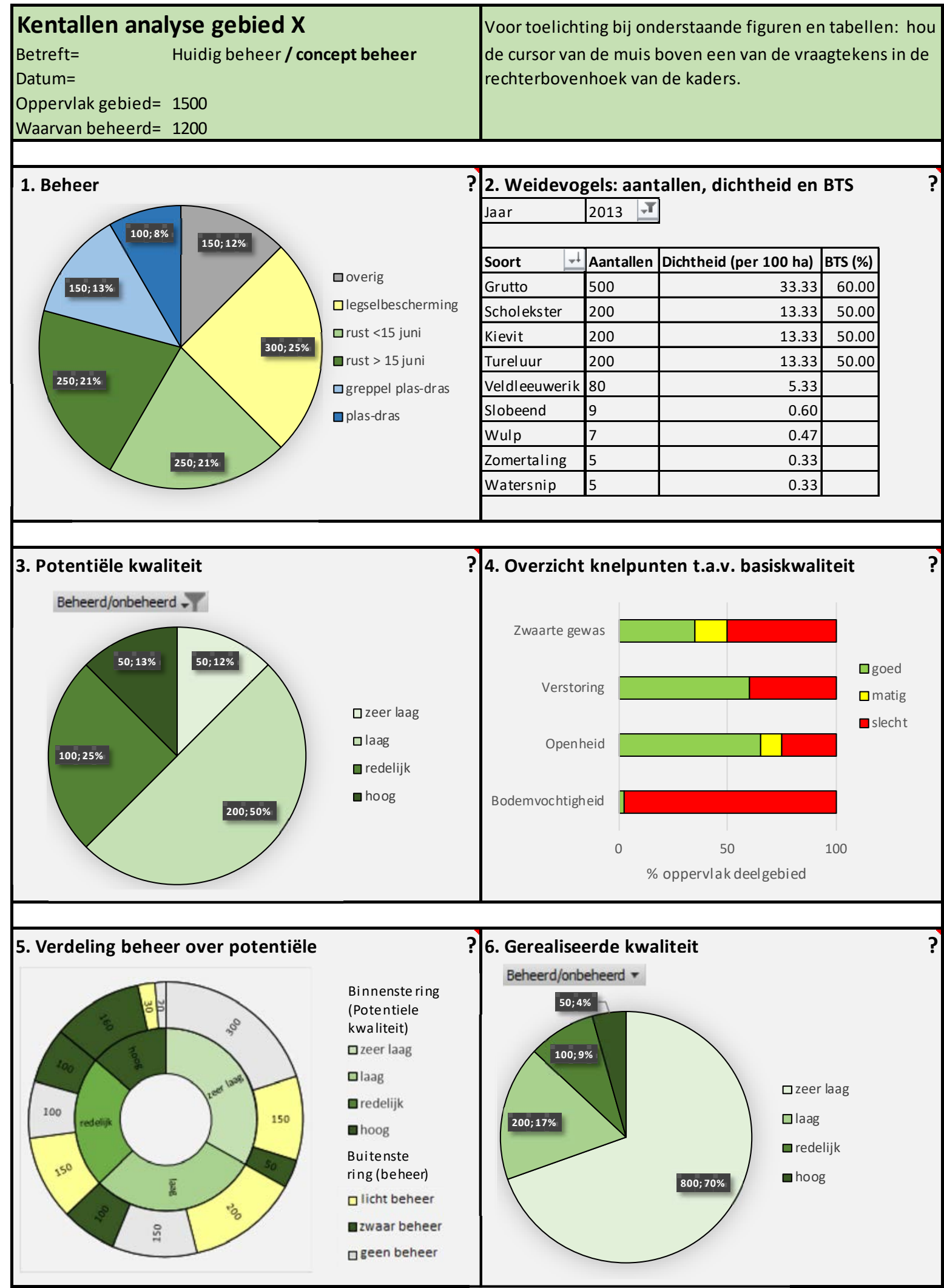

Figuur 1 Kentallenanalyse (nummers corresponderen met beschrijving in bovenstaande tekst). 

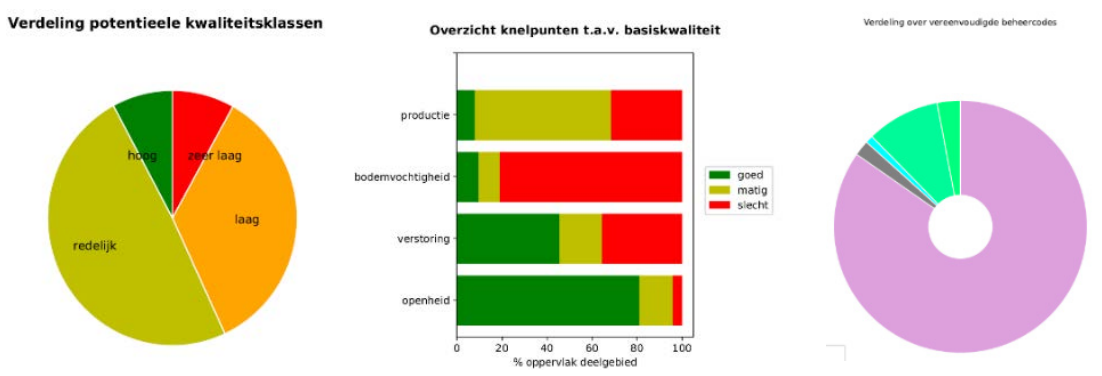

Verdeling gerealiseerde kwaliteitsklassen
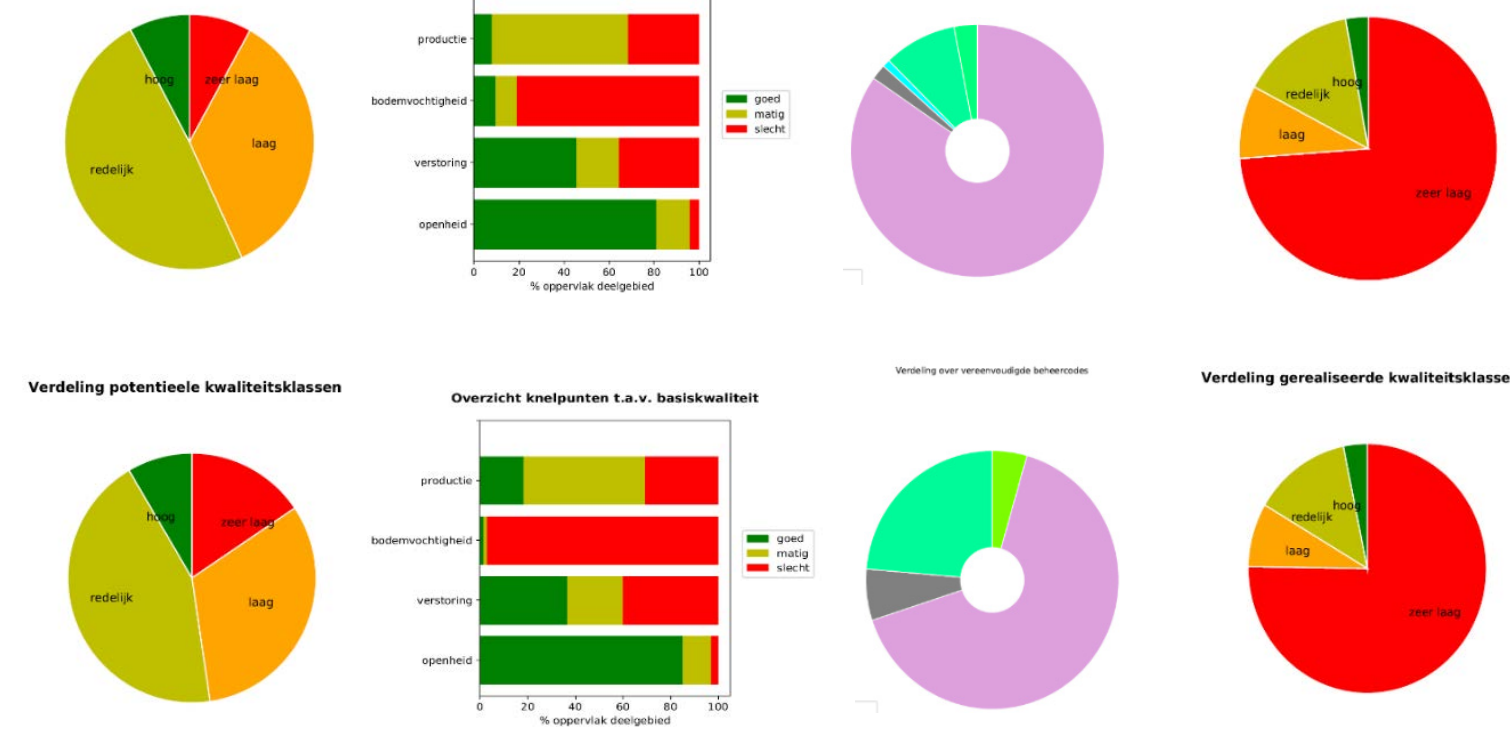

Verdeling potentieele kwaliteitsklasse
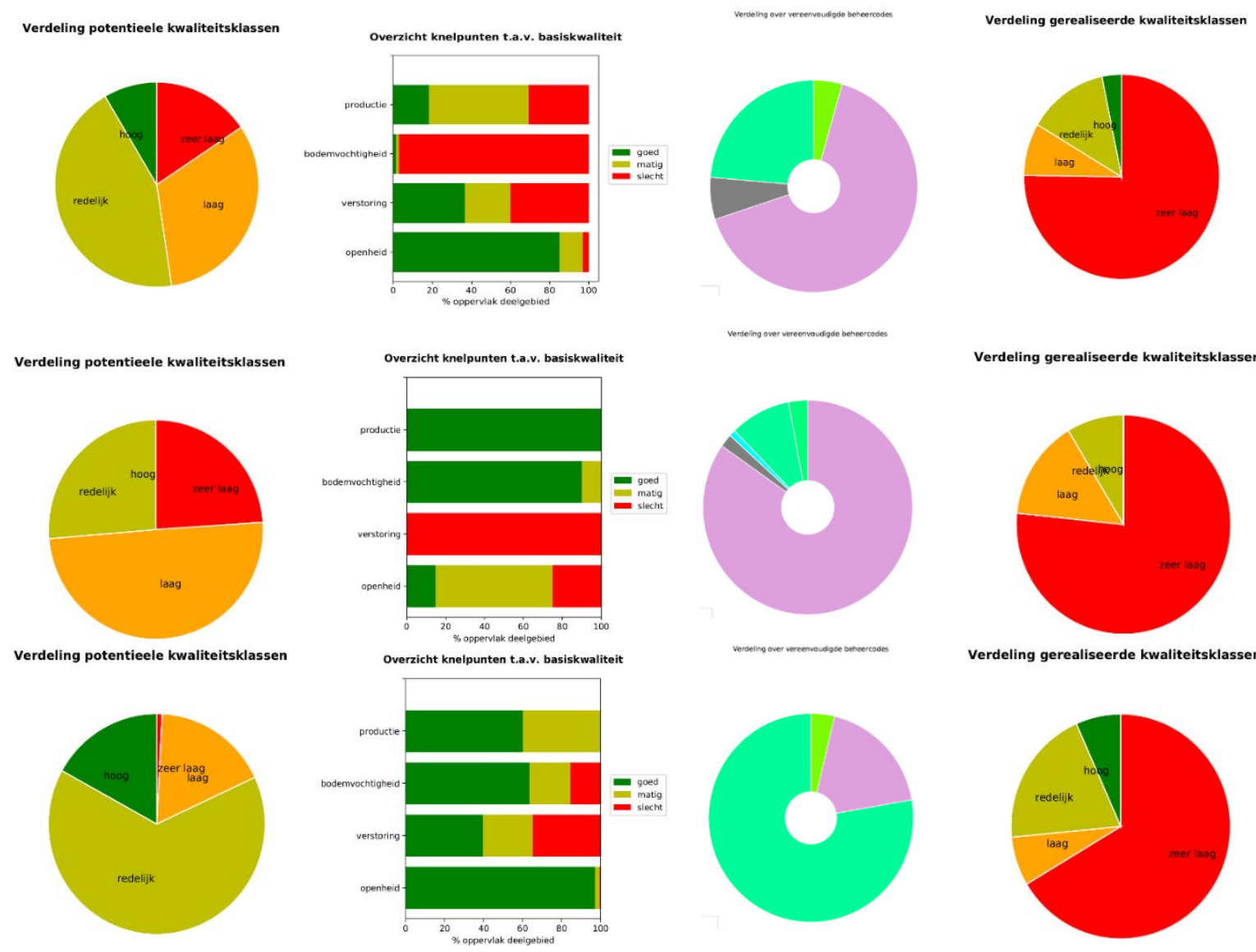

Verdeling gerealiseerde kwaliteitsklassen

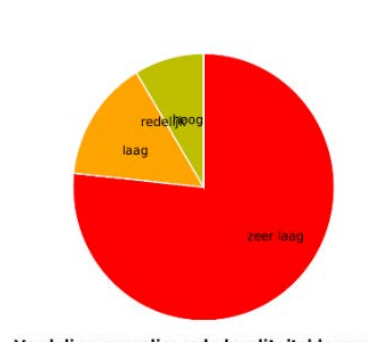

Verdeling gerealiseerde kwaliteitsklassen

$$
\begin{aligned}
& \text { Extensieve beweiding } \\
& =\text { Legselbeheer } \\
& \text { Overig } \\
& \text { Plasdras } \\
& \\
& =\text { Uitgesteld maaien }<15 \text { juni } \\
& \text { Vitgesteld maaien }>15 \text { juni } \\
&
\end{aligned}
$$

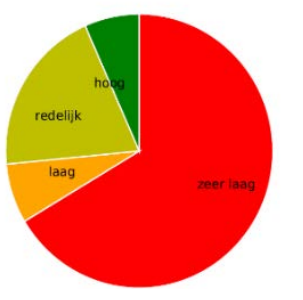

Figuur 1a De kentallen weidevogelbeheer geven in acht items een cockpitview over de toestand in weidevogelgebieden. Deze zijn voor alle circa 280 BTS-gebieden berekend die LandschappenNL onderscheidt. Deze kentallen karakteriseren een aantal weidevogel-relevante kenmerken. Bij wijze van illustratie worden hieronder van vier gebieden vier kenmerken weergegeven. De figuren laten zien hoe de gebieden van elkaar verschillen en hoe dit resulteert in potentiële kwaliteit, verbeteropgaven in het gebied, verdeling van de verschillende beheervormen en de gerealiseerde habitatkwaliteit.

\subsection{Uitbreiding BoM naar andere leefgebiedtypen}

De uitbreiding van Beheer-op-Maat naar de leefgebiedtypen 'droge dooradering' en 'open akkers' is mede opgepakt in een tweetal parallel uitgevoerde projecten: project 'MNP-agrarisch' (Visser et al., 2019a) en project 'Habitatkwaliteit ANLb' (in voorbereiding, Visser et al., 2020). De resultaten van die projecten kunnen goed worden benut in BoM. Hieronder zijn de voor BoM relevante en belangrijkste resultaten van beide projecten opgenomen. Deze worden kort besproken. 


\section{MNP Agrarisch}

\section{Achtergrond \& aanleiding}

Het Planbureau voor de Leefomgeving (PBL) rekent de effecten van beleidsscenario's op de natuur door. Voor landnatuur is enkele jaren geleden een kernmodelinstrumentarium ontwikkeld (Model for Nature Policy (MNP)), gericht op het Nationaal Natuur Netwerk (NNN). Daarin werd beperkt aandacht geschonken aan de factor beheer. Om de effecten van beleidsscenario's ook voor het agrarisch gebied door te kunnen rekenen (denk aan vergroening GLB, beperking $\mathrm{CO}_{2}$-emissie door aanpassing van de ontwatering e.d.), is gebruikgemaakt van een systematiek die sterk verwant is met die van BoM (vanaf dit punt aangeduid als MNP-Agrarisch).

\section{Doelstelling}

Het doel van het project was om een model te ontwikkelen dat de effecten van landelijke (beleids)scenario's op de natuur in het agrarisch gebied kan doorrekenen.

\section{Soortselectie}

Voor de modellering kwamen soorten in aanmerking die binnen de ANLb-2016 doelsoorten zijn en/of soorten die al in het huidige MNP zijn opgenomen. Van de toen tien geselecteerde soorten zijn er zeven relevant voor de uitbreiding van Beheer-op-Maat en wel voor de leefgebiedtypen 'droge dooradering' en 'open akker'. Het betreft de volgende soorten:

- Droge dooradering: patrijs, geelgors

- Open akker: Grauwe kiekendief, kievit, patrijs, veldleeuwerik, torenvalk, hamster

\section{Werkwijze model}

De methode is samengevat weergegeven in Figuur 2. In hoofdlijnen werkt de methode als volgt:

1. De abiotische condities (openheid, drooglegging, verstoring, zwaarte gewas, bodemtype) worden opgedeeld in klassen en worden op kaart weergegeven. Aan iedere klasse is een weegwaarde gekoppeld tussen 0 en 1 die de geschiktheid aangeeft voor een specifieke soort.

2. De losse kaartbeelden worden geïntegreerd tot één kaartbeeld door de weegwaarden uit de losse kaartbeelden met elkaar te vermenigvuldigen. Het resultaat is een kaart die aantoont waar in potentie geschikt leefgebied voorkomt voor een specifieke soort, ook wel aangeduid als de 'potentiële kwaliteit'.

3. De potentiële kwaliteit wordt vermenigvuldigd met de weegwaarde van het beheertype. Dit wordt tweemaal gedaan: eenmaal met de weegwaarde als foerageerhabitat en eenmaal met de weegwaarde als reproductiehabitat.

4. Op basis van het kaartbeeld 'gerealiseerde kwaliteit reproductiehabitat' vallen gebieden met onvoldoende geschikt reproductiehabitat af. Hetzelfde gebeurt wanneer er onvoldoende foerageerhabitat beschikbaar is binnen de actieradius van de soort ten opzichte van het reproductiehabitat. Het eindresultaat is een kaartbeeld met geschikt leefgebied (= gebieden met voldoende geschikt reproductiehabitat (kwaliteit + omvang) en voldoende geschikt foerageerhabitat (kwaliteit + omvang) binnen de actieradius van de soort. De benodigde methodiek voor deze stap is reeds volledig uitgedacht, de operationalisering kan eventueel in een vervolg worden opgepakt.

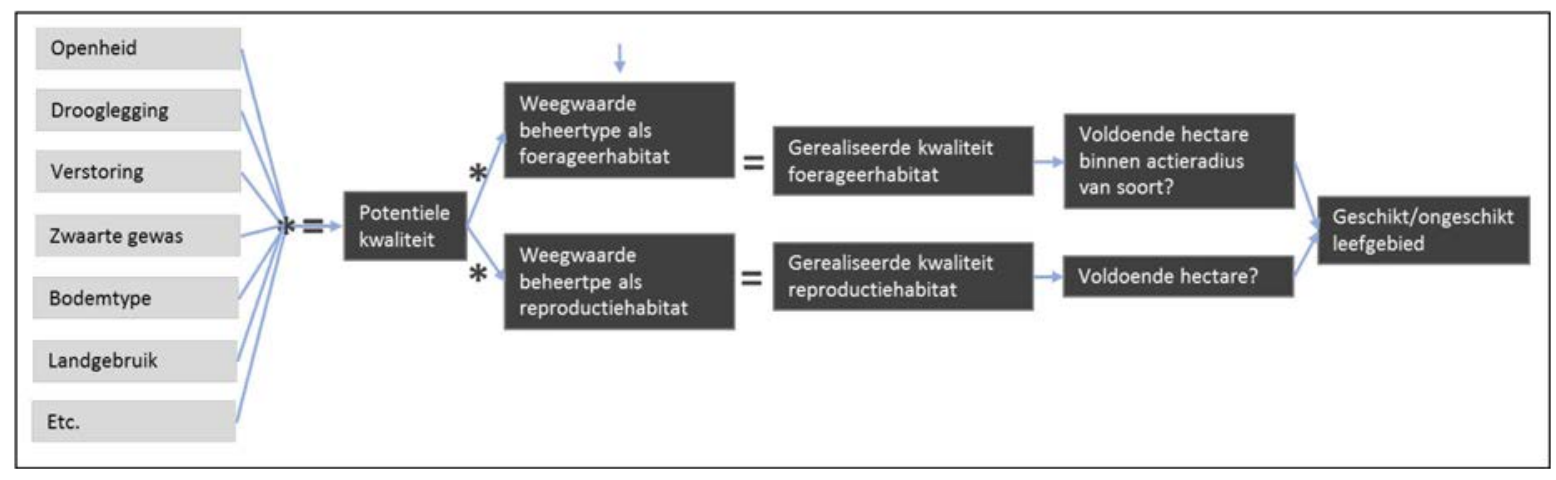

Figuur 2 Samenvatting model. 
Hoe verhoudt dit zich tot de methode in Beheer-op-Maat?

De eerste drie stappen komen vrijwel geheel overeen met de methodiek zoals die momenteel bestaat voor Beheer-op-Maat. Het enige verschil betreft de toevoeging van het onderscheid tussen reproductie- en foerageerhabitat. Voor weidevogels is dit onderscheid binnen het kennissysteem Beheer-op-Maat niet gemaakt, omdat de optimale habitat voor foerageren en reproduceren bij weidevogels grotendeels overeenkomt; er is geen sprake van een ruimtelijke scheiding van habitat zoals dat voor soorten die voorkomen in de leefgebiedtypen open akker en droge dooradering vaak wel het geval is.

Voor stap 1 (integreren abiotische condities) is binnen Beheer-op-Maat tot nu toe gewerkt met vier abiotische factoren: verstoring, openheid landschap, bodemvochtigheid, zwaarte gewas. Binnen het MNP-agrarisch project zijn daar 'bodemtype' en 'kleinschaligheid' aan toegevoegd, die voor enkele soorten in de berekening worden meegenomen.

Stap 4 van MNP-Agrarisch, het combineren van de reproductie- en het foerageerhabitat, betreft een volledig nieuwe stap. Tot op heden werden de functies m.b.t. reproductie- en foerageerhabitat niet van elkaar gescheiden binnen de modellering, mede omdat deze scheiding voor weidevogels nauwelijks een rol speelt. Voor een groot aantal doelsoorten van het ANLb zal het noodzakelijk zijn om dit onderscheid te maken om tot een goede modellering te komen.

Deze stap is conceptueel uitgewerkt, maar nog niet operationeel in BoM. Operationalisering van deze stap kan de betrouwbaarheid van de uitkomsten sterk ten goede komen. Naast technische uitdagingen vormt een gebrek aan informatie met betrekking tot de actieradius en de benodigde omvang van het habitat een uitdaging voor operationalisering.

\section{Resultaten}

De modeluitkomsten zijn tweeledig: 1) de potentiële kwaliteit, 2) de gerealiseerde kwaliteit, overeenkomstig met de methodiek zoals gebruikt voor Beheer-op-Maat. De modeluitkomsten worden getoond op een celniveau van 25×25 meter. De verspreidingskaarten zijn veel grover ( $5 \times 5$ kilometer). Ter illustratie zijn op de volgende pagina's de resultaten voor de patrijs en grauwe kiekendief weergegeven. Voor de uitkomsten van alle gemodelleerde soorten: zie de MNP-Agrarisch rapportage (Visser et al., 2019a).

\section{Patrijs}

De kaartbeelden van de actuele verspreiding en de berekende kwaliteiten komen goed overeen (door de schaal van onderstaande kaarten moeilijk te herkennen: patrijzenhabitat bestaat uit een verzameling van relatief kleine landschapselementen, die wegvallen op een kaartbeeld op nationale schaal). Voor een groot aandeel van de gebieden lijkt voldoende aanbod van geschikt broedgebied limiterend te zijn. In algemene zin valt op dat gebieden met een 'zeer hoge' potentiële kwaliteit schaars zijn, abiotische factoren zijn dus niet optimaal. Bovendien is duidelijk zichtbaar dat de gebieden met een hoge potentiële kwaliteit niet optimaal worden benut met het beheer: in de gerealiseerde kwaliteit is slechts een zeer klein aandeel van deze hoge kwaliteitsklassen overgebleven. 


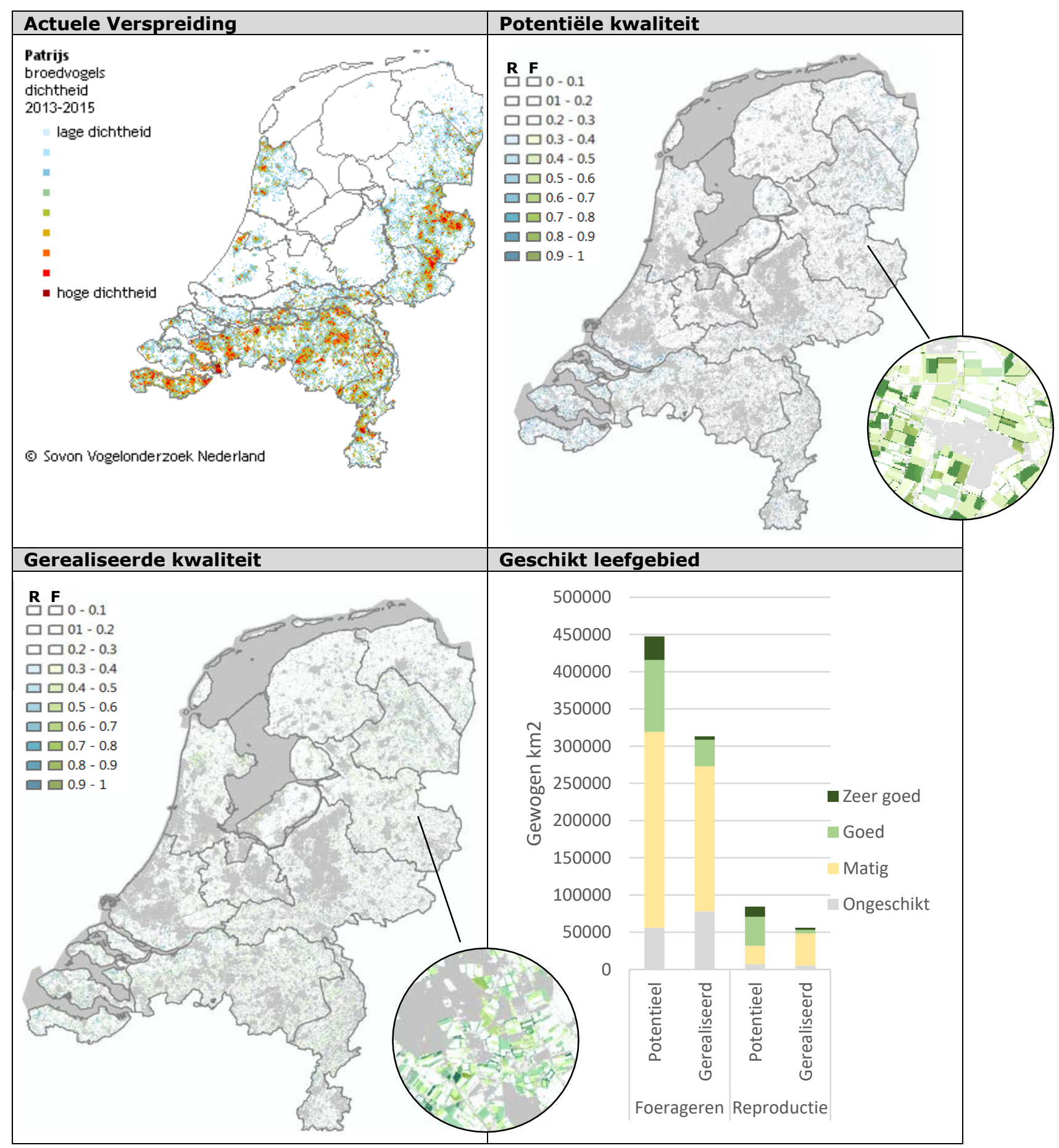

Figur 3 Bovenstaand figur toont de actuele spreiding voor de patrijs, de gemodelleerde potentiële kwaliteit (= geschiktheid in termen van abiotische condities) en de gemodelleerde gerealiseerde kwaliteit (product van de potentiële kwaliteit en het beheer). De grijze vlakken vallen buiten de scope van het model (= stad, alle natuurgebieden m.u.v. akker en graslandreservaten, meren, etc.).

\section{Grauwe kiekendief}

De potentiële kwaliteitskaart toont omvangrijk geschikt leefgebied in met name Zeeland, Flevoland en Noordoost-Groningen. Momenteel is het voorkomen van de grauwe kiekendief echter beperkt tot Noordoost-Groningen. In het verleden werd ook in relatief hoge dichtheden gebroed in Flevoland en sporadisch in Zeeland. De potentiële kwaliteitskaart duidt deze gebieden nog steeds aan als potentieel geschikt leefgebied. Naar alle waarschijnlijkheid zijn factoren die gerelateerd aan het beheer/landgebruik bepalend geweest voor het verdwijnen van de grauwe kiekendief in deze gebieden. In Groningen heeft grootschalige braaklegging geleid tot vestiging, wellicht dat de toepassing van deze maatregel in (delen van) Flevoland en Zeeland (op termijn) tot hetzelfde 
resultaat kan leiden. Een kanttekening bij de modeluitkomsten is dat ervan uit is gegaan dat in geschikte gebieden nestbescherming wordt toegepast. De werkelijkheid is weerbarstiger: er zijn gebieden waar niet naar nesten wordt gezocht en er worden nesten gemist tijdens de inventarisatie. Deze nesten zullen zonder nestbescherming hoogstwaarschijnlijk verloren gaan.

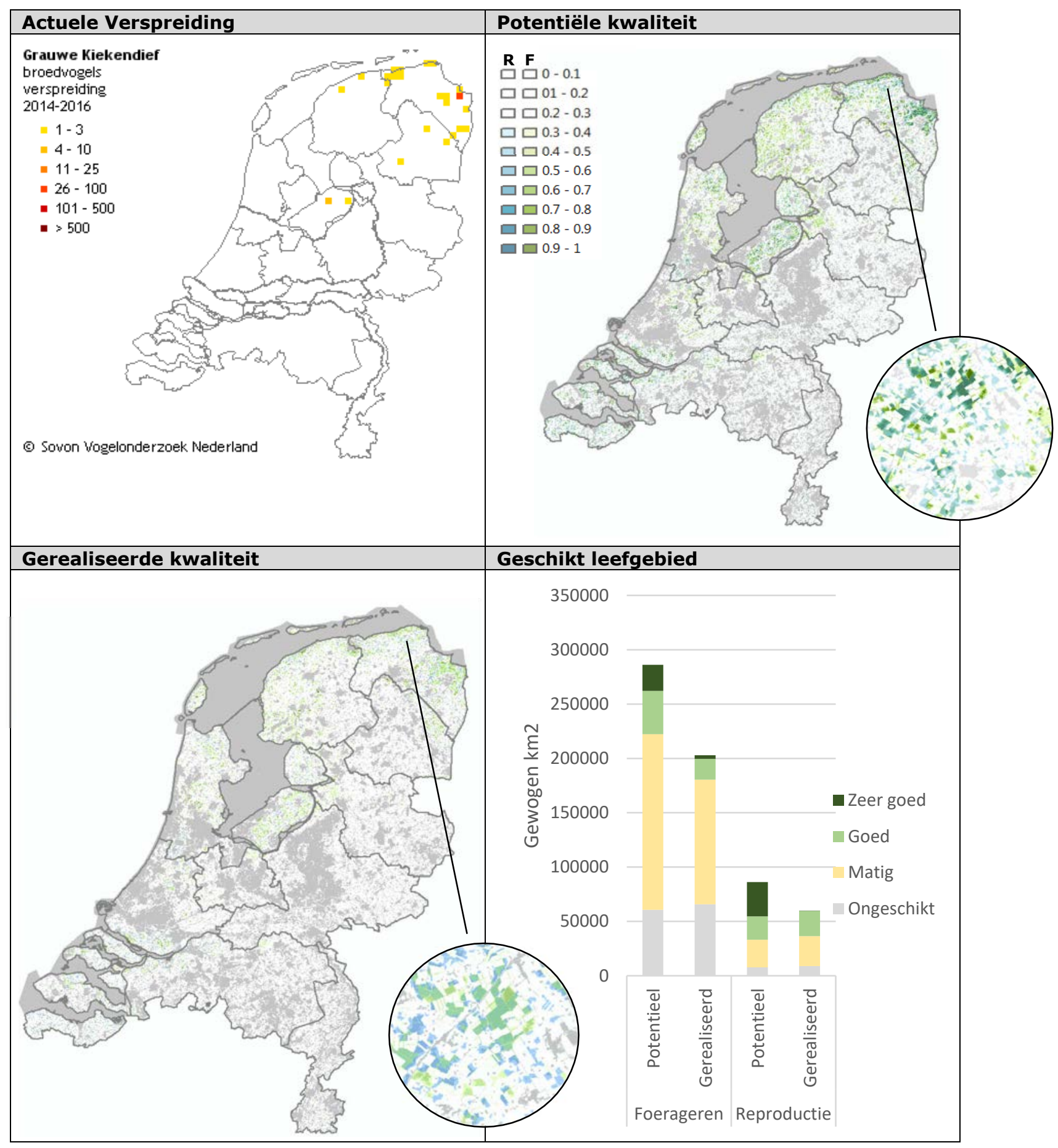

Figuur 4 Bovenstaand figuur toont de actuele spreiding voor de grauwe kiekendief, de potentiële kwaliteit (= geschiktheid in termen van abiotische condities) en de gemodelleerde gerealiseerde kwaliteit product van de potentiële kwaliteit en het beheer). De grijze vlakken vallen buiten de scope van het model (= stad, alle natuurgebieden m.u.v. akker en graslandreservaten, meren, etc.).

\section{Evaluatie resultaten}

De eerste uitkomsten van het model (potentiële en gerealiseerde kwaliteitskaarten) lijken aan te geven dat we op de goede weg zitten. De berekende kaartenbeelden komen op hoofdlijnen goed overeen met de actuele verspreidingskaarten. Dat geldt met name voor het herkennen van de 
belangrijke landschapstypen/regio's. Voor de meer gedetailleerde ruimtelijke invulling (op polder of op perceelniveau is de beschikbare informatie nog niet toereikend. Alleen voor weidevogels zijn dergelijke exercities beschikbaar. De kalibratie, die beperkt is uitgevoerd, lijkt vooralsnog bevredigend (Melman et al., 2016). Voor de andere soorten valt op dat de zwaartepunten van de geschikte gebieden goed gedetecteerd worden, maar dat de omvang van de gebieden verschillen lijkt te geven. Of dit verschil feitelijk aan de orde is, kan op dit moment niet worden bepaald. Wellicht hangt het voor een belangrijk deel samen met de ruimtelijke resolutie van de beschikbare gegevens en het ontbreken van enkele belangrijke kaartlagen (struwelen, bermbeheer, locaties nestkasten, etc.).

\section{Enkele kanttekeningen bij de uitbreiding van het kennissysteem Beheer-op-Maat}

Enkele belangrijke habitatelementen (zoals struwelen) zijn momenteel niet opgenomen in het model, vanwege het ontbreken van geschikt kaartmateriaal. Dit bemoeilijkt het modelleren van soorten die sterk aan deze elementen verbonden zijn (bijvoorbeeld braamsluiper en roodborsttapuit). Mogelijk dat de kaartbeelden die nu in ontwikkeling zijn een uitkomst gaan bieden, waardoor deze soorten alsnog kunnen worden toegevoegd aan het model.

Een andere belangrijke uitdaging betreft het onderscheid van gewastypen. Binnen het model wordt een aantal gewastypen van elkaar onderscheiden (aardappelen, bieten, granen, mais \& bloembollen). Alle overige gewastypen vallen binnen de categorie 'overig'. Wellicht dat hier in de toekomst differentiatie in kan worden aangebracht, waarbij ecologisch belangrijke gewassen - zoals luzerne als losse categorie worden toegevoegd.

\section{Kwaliteitsklassen ANLb}

In BoM wordt gewerkt met een aantal parameters die de habitatkwaliteit voor een doelsoort bepalen. De parameters zijn veelal continu van karakter. Voor gebruik in de praktijk is het handzaam om met klassen te werken. Zo worden voor landschappelijke openheid de volgende klassen onderscheiden: $>600 \mathrm{~m}, 300-600 \mathrm{~m}, 150-300 \mathrm{~m}, 50-150 \mathrm{~m},<50 \mathrm{~m}$. Iets vergelijkbaars geldt voor drooglegging, verstoring en zwaarte van het gewas. Uiteindelijk doel is van een bepaalde plek of een bepaald gebied aan te kunnen geven in welke mate deze voldoet aan de habitateisen van de betreffende soort. De klasse-indeling wordt daarom verbonden met een normatieve waardering, in termen van goed (voldoend), matig (voldoend) of slecht (voldoend). Aan het bepalen van klassegrenzen kleeft onvermijdelijk een subjectief element: wanneer voldoet iets goed of slecht? Uiteindelijk zou je dat altijd moeten kunnen doorvertalen naar wel of niet strokend met wat een duurzame populatie nodig heeft. En dat niet voor één factor, maar voor alle factoren gezamenlijk. En om het nog gecompliceerder te maken: hoeveel areaal van een goede kwaliteit is nodig qua openheid, vochttoestand, etc. Om dit volledig te onderbouwen, is de beschikbare kennis bij lange na niet toereikend, nu niet en ook in de verre toekomst niet. Dergelijke klassegrenzen en integrale beoordelingen hebben onvermijdelijk het karakter van een expert judgement. Deze problematiek is een van de elementen dat onderdeel zou moeten zijn van het lerend beheer.

Toch zijn voor een gebied uiteindelijk uitspraken wenselijk over of het gebied wel dan niet toereikend is voor het duurzaam in stand houden van een populatie van een doelsoort. En ook is het wenselijk om daarmee gebieden te kunnen vergelijken. Daarom hebben we voor de belangrijkste habitatfactoren kwaliteitsklassen onderscheiden, zo veel mogelijk op basis van wetenschappelijk onderzoek en waar dat niet mogelijk is, op basis van expert judgement of praktijkervaring. Bij het gebruik van kwaliteitsklassen is het goed deze achtergrond te kennen.

Het voordeel van gebruik van kwaliteitsklassen is dat het de habitatkwaliteit en de onderdelen daarvan concreet en kwantitatief beschrijft. De habitatkwaliteit in een bepaald gebied wordt daarmee bespreekbaar en toetsbaar. Aan het realiseren van verbeteringen kunnen concrete beheer- en inrichtingsmaatregelen worden gekoppeld. Het beste gebruik van de kwaliteitsklassen is wellicht om gebieden met elkaar te vergelijken. Door deze vergelijking van habitatkwaliteit te koppelen aan ontwikkelingen in de populatie kan het lerend beheer onderbouwd gestalte krijgen. 


\subsection{Applicatiebeheer BoM-weidevogels}

\subsubsection{Verfijning losse factoren}

\section{Update bodemvochtigheidskaart}

De bodemvochtigheidskaart is verfijnd. Tot op heden werd gebruikgemaakt van een droogleggingskaart die het product is van de vergelijking van het peilbesluit en de maaiveldhoogte. Binnen de vernieuwde bodemvochtigheidskaart wordt ook rekening gehouden met kwel en het bodemtype.

De vernieuwde bodemvochtigheidskaart wordt als volgt berekend:

1. Berekenen drooglegging: de drooglegging is berekend door de maaiveldhoogte (op basis van het Algemeen Hoogtebestand Nederland) te vergelijken met het vigerende peilbesluit. Hierbij is gebruikgemaakt van het waterpeil in de winter, omdat uit onderzoek in Noord-Holland is gebleken (Schotman et al., 2008) dat de drooglegging in de winter een belangrijke relatie heeft met de trend van weidevogels en het voorkomen van natte en vochtige graslanden tijdens het broedseizoen.

2. Vertalen van de drooglegging in centimeters naar klasse-indeling bodemvochtigheid, rekening houdend met het bodemtype: het bodemtype is van grote invloed op de relatie tussen de drooglegging en de bodemvochtigheid. Zo leidt een drooglegging van $35 \mathrm{~cm}$ op veengrond tot een redelijk vochtige bodem, terwijl een drooglegging van $35 \mathrm{~cm}$ op zandgrond leidt tot een relatief droge bodem. Om deze reden is bij het vertalen van de feitelijke drooglegging (in centimeters) naar de klasse-indeling van de bodemvochtigheid (nat, vochtig, droog) rekening gehouden met het bodemtype. Dit is gedaan door de klassegrenzen per bodemtype te differentiëren (zie onderstaande tabel). De klassegrenzen en differentiatie per bodemtype zijn gebaseerd op onderzoek van Teunissen et al. (2012). Uit dit onderzoek kan de droogleggingswaarde per bodemtype worden afgelezen waarop $75 \%$ van de populaties een negatieve/positieve ontwikkeling kent.

\begin{tabular}{|c|c|c|}
\hline Klasse & Klasse-omschrijving & $\begin{array}{l}\text { Klassegrenzen ( } \mathrm{cm} \text { t.o.v. maaiveld voor veen, zand, klei en } \\
\text { overig) }\end{array}$ \\
\hline 1 & Nat & $\begin{array}{l}\text { Drooglegging kleiner dan } 20 \text { (veen), } 30 \text { (klei op veen), } 45 \text { (klei), } \\
15 \text { (zand) cm onder maaiveld. }\end{array}$ \\
\hline 2 & Vochtig & $\begin{array}{l}\text { Drooglegging tussen } 20-35 \text { (veen), } 30-50 \text { (klei op veen), } \\
45-70 \text { (klei), } 15-30 \text { (zand) cm onder maaiveld. }\end{array}$ \\
\hline 3 & Droog & $\begin{array}{l}\text { Drooglegging groter dan } 35 \text { (veen), } 50 \text { (klei op veen), } 70 \text { (klei), } \\
30 \text { (zand) cm onder maaiveld. }\end{array}$ \\
\hline
\end{tabular}

3. Rekening houden met kwel en wegzijging: het optreden van kwel en wegzijging kan de bodemvochtigheid beïnvloeden. Om deze reden is op locaties waar kwel/wegzijging optreedt de drooglegging gecorrigeerd. Voorbeeld: de drooglegging op locatie $X$ (veenbodem) is $40 \mathrm{~cm}$. Locatie $X$ wordt daarom ingedeeld in klasse 3: te droog. Echter, doordat op deze locatie zeer sterke kwel optreedt ( $>0.5 \mathrm{~mm} / \mathrm{etm}$ ) wordt de drooglegging van locatie $X$ verkleind met $10 \mathrm{~cm}$. De drooglegging is daardoor verkleind tot $30 \mathrm{~cm}$, waardoor locatie $X$ wordt heringedeeld in klasse 2: vochtig. De grootte van de correctie is gebaseerd op de relatie tussen kweldruk en het effect op de bodemvochtigheid (Jansen e.a., 2009):

- Kweldruk $>0.5 \mathrm{~mm} / \mathrm{etm}(\mathrm{kwel})=-10 \mathrm{~cm}$

- Kweldruk $<0.5 \mathrm{~mm}$ en $>-0.5$ (intermediair) $=-4 \mathrm{~cm}$

- Kweldruk $<-0.5 \mathrm{~mm}$ (wegzijging) $=+2 \mathrm{~cm}$

De hierboven beschreven rekenwijze heeft geleid tot een vernieuwde bodemvochtigheidskaart (zie Figuur 5) die in 2019 is gepubliceerd op de webtool van Beheer-op-Maat. 


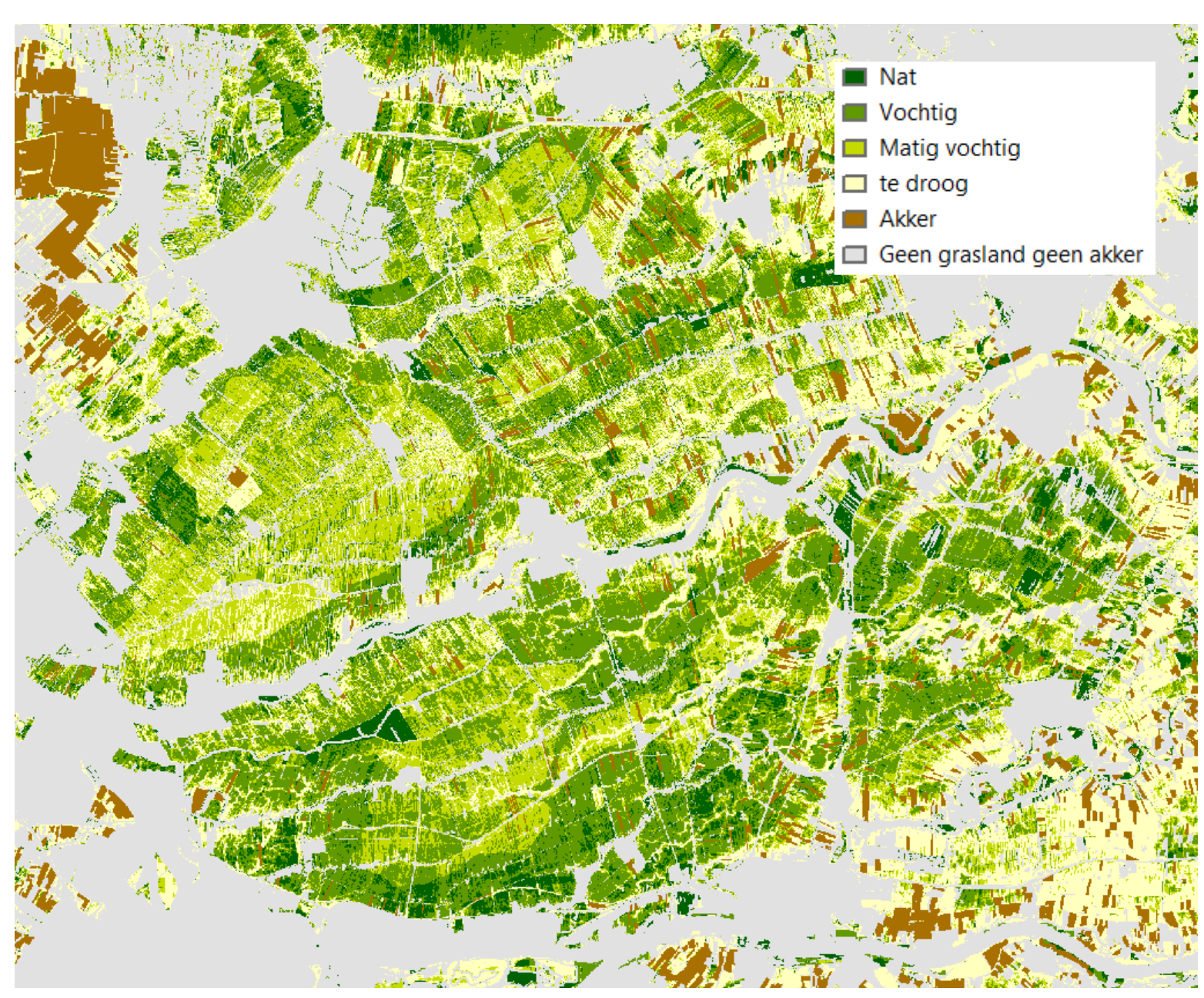

Figur 5 Vernieuwde bodemvochtigheidskaart.

\section{Update openheid landschap}

In 2019 is de kaart met betrekking tot de openheid van het landschap vernieuwd (zie Figuur 6). De vorige versie dateerde uit 2012. De kaart is het resultaat van het zogenaamde viewscapemodel (Meeuwsen \& Jochem, 2011). In dit model worden opgaande structuren zoals bomenrijen en bebouwing beschouwd als ondoorzichtige elementen. Het model rekent voor 4,5 miljoen locaties in Nederland uit wat de zichtafstand is. Dit wordt gedaan door vanaf de locatie in kwestie zichtlijnen te trekken in alle richtingen (360 graden) (zie onderstaande figuur). De lengte van de zichtlijn is afhankelijk van de aanwezigheid van opgaande structuren. Daar waar opgaande structuren afwezig zijn, is de zichtlijn lang (tot maximaal $1500 \mathrm{~m}$ ). Daar waar opgaande structuren aanwezig zijn, is de zichtlijn korter. De openheid van de locatie kan uiteindelijk worden bepaald door de gemiddelde lengte van de zichtlijnen in alle richtingen te nemen. 


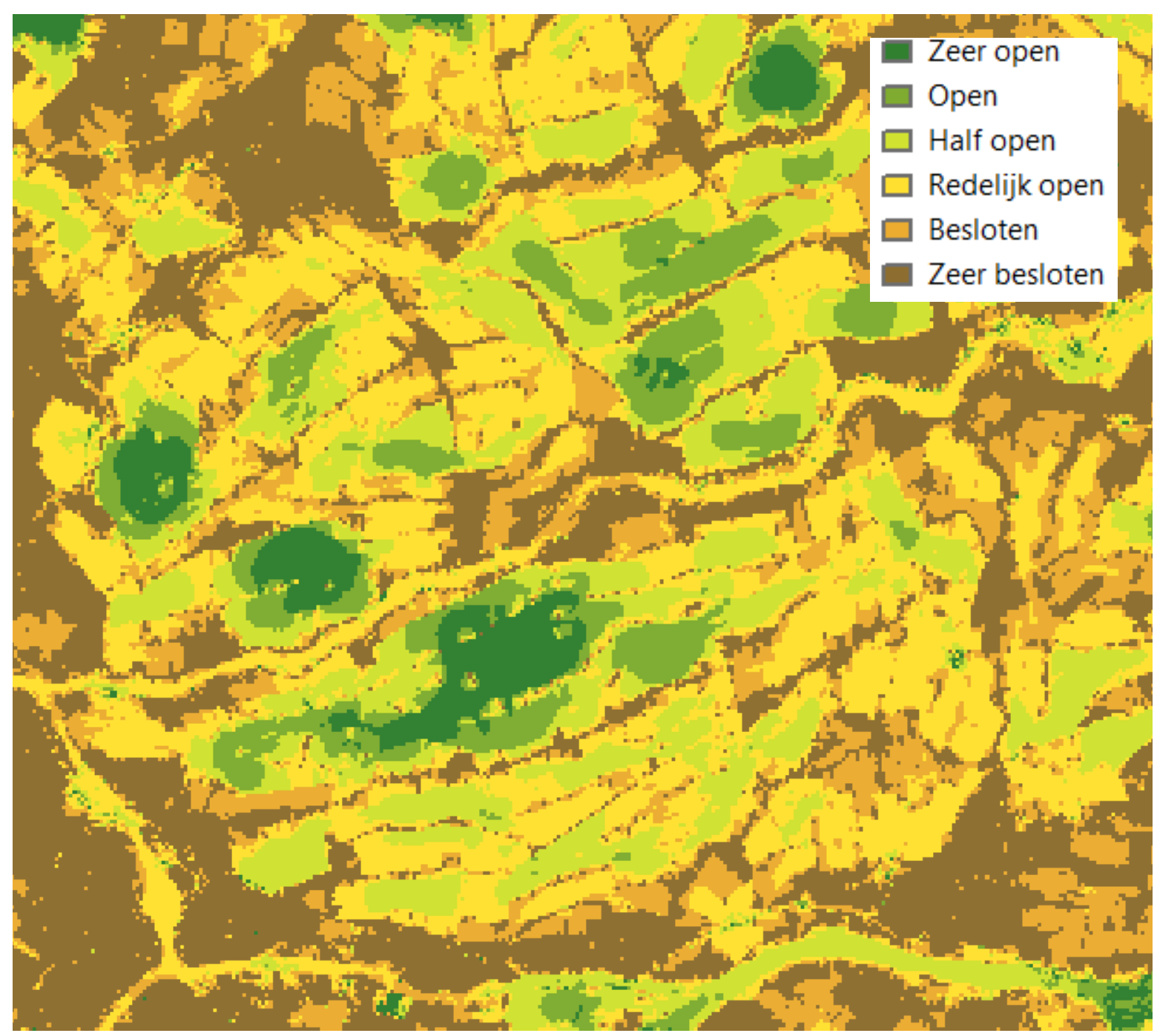

Figur 6 Openheid landschap.

\section{Update zwaarte gewas}

De kaart met betrekking tot de zwaarte van het gewas is geüpdatet op twee vlakken:

- Kaartbeeld is gebaseerd op nieuwe data uit de maanden februari-april in de jaren 2017, 2018 en 2019.

- Weergave van kaart aangepast $\rightarrow$ voorheen had de kaart een continu-schaal, hetgeen het moeilijk maakt om het kaartbeeld te interpreteren. Om deze reden is in de vernieuwde versie gewerkt met klassen, die tevens de koppeling met de rekenregels beter inzichtelijk maken (rekenregels werken ook met klassen). Zie Figuur 7 voor de nieuwe versie. 


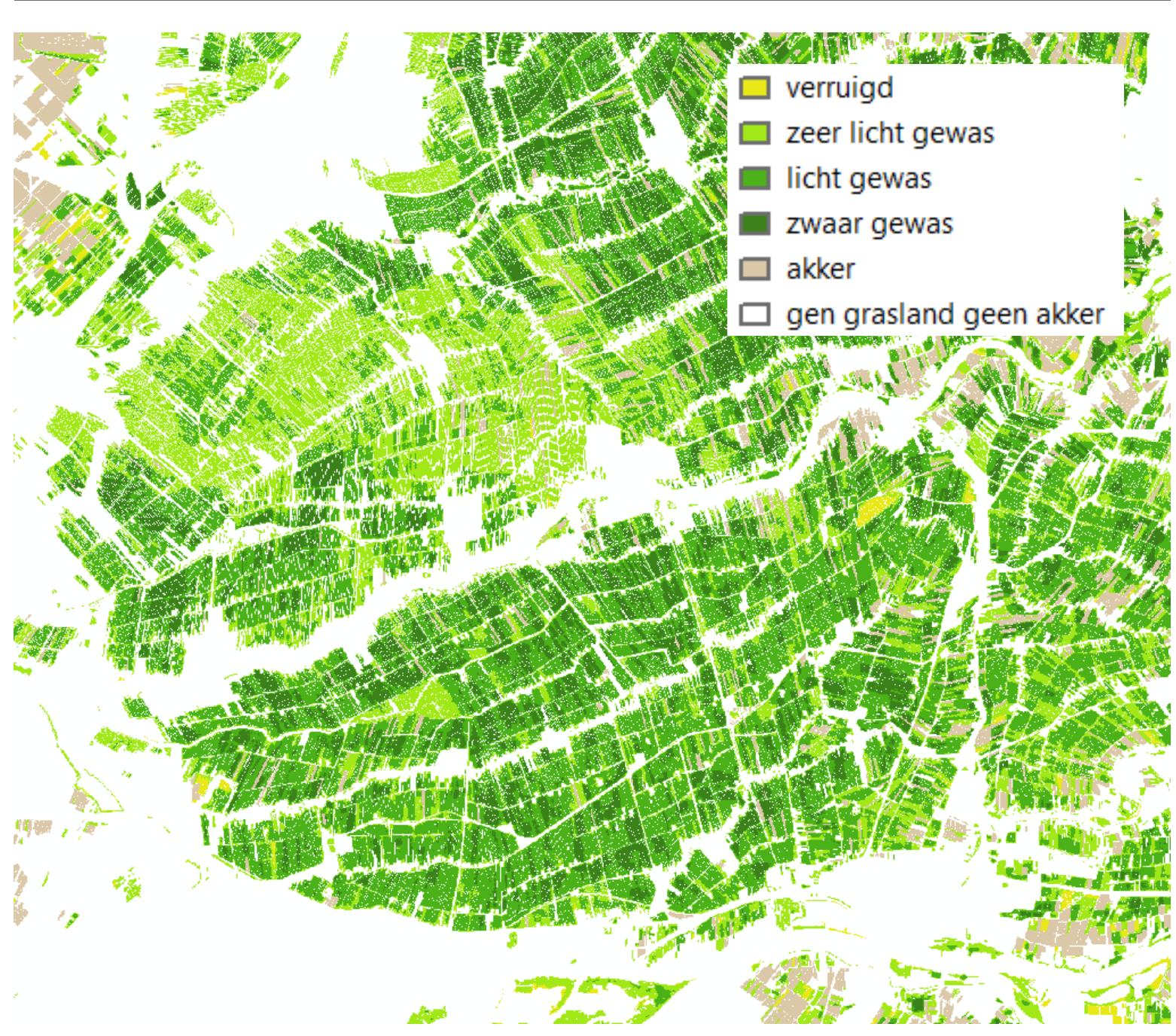

Figuur 7 Zwaarte gewas.

\section{Update verstoring}

De kaart met betrekking tot de aanwezigheid van verstorende elementen is vernieuwd. In de vorige versie was een cel wel of niet verstoord. In de vernieuwde versie wordt gewerkt met gradaties van verstoring.

\section{Totstandkoming kaart}

Bij het ontwikkelen van de verstoringskaart is rekening gehouden met de volgende aspecten:

- De mate waarin een verstorend effect optreedt, is afhankelijk van de verstoringsbron (zo heeft een bomenrij een 'groter' verstorend effect dan een fietspad, mede omdat het verstorende effect van een bomenrij constant is. Dit in tegenstelling tot bijvoorbeeld het verstorende effect van een fietspad, dat in de tijd varieert (als gevolg van de variërende drukte op het fietspad).

- Het verstorende effect neemt af naarmate de afstand ten opzichte van de verstorende bron toeneemt.

- Het verstorende effect differentieert per soort. Hierbij geldt dat de scholekster het minst gevoelig is, gevolgd door de kievit (gevoelig) en ten slotte de tureluur en grutto (zeer gevoelig) (Kleijn et al., 2009).

Het verstorende effect is ingedeeld in vijf klassen (van licht verstoord (klasse 1) naar zwaar verstoord (klasse 5)). In Tabel 1 is weergegeven hoe deze klassen zijn toegekend aan de verschillende verstoringsbronnen, per afstand ten opzichte van deze verstoringsbron. 
Tabel 1 De mate van verstoring per verstoringsbron, per afstand t.o.v. deze verstorende bron. Betekenis getallen: $0=$ niet verstoord, $1=$ zeer licht verstoord, $2=$ licht verstoord, 3=verstoord, 4=zwaar verstoord, 5=zeer zwaar verstoord. (Voor onderbouwing van de verstoringsafstanden, zie: Teunissen et al., 2012; Bruinzeel \& Schotman, 2011; Sierdesma et al., 2013.)

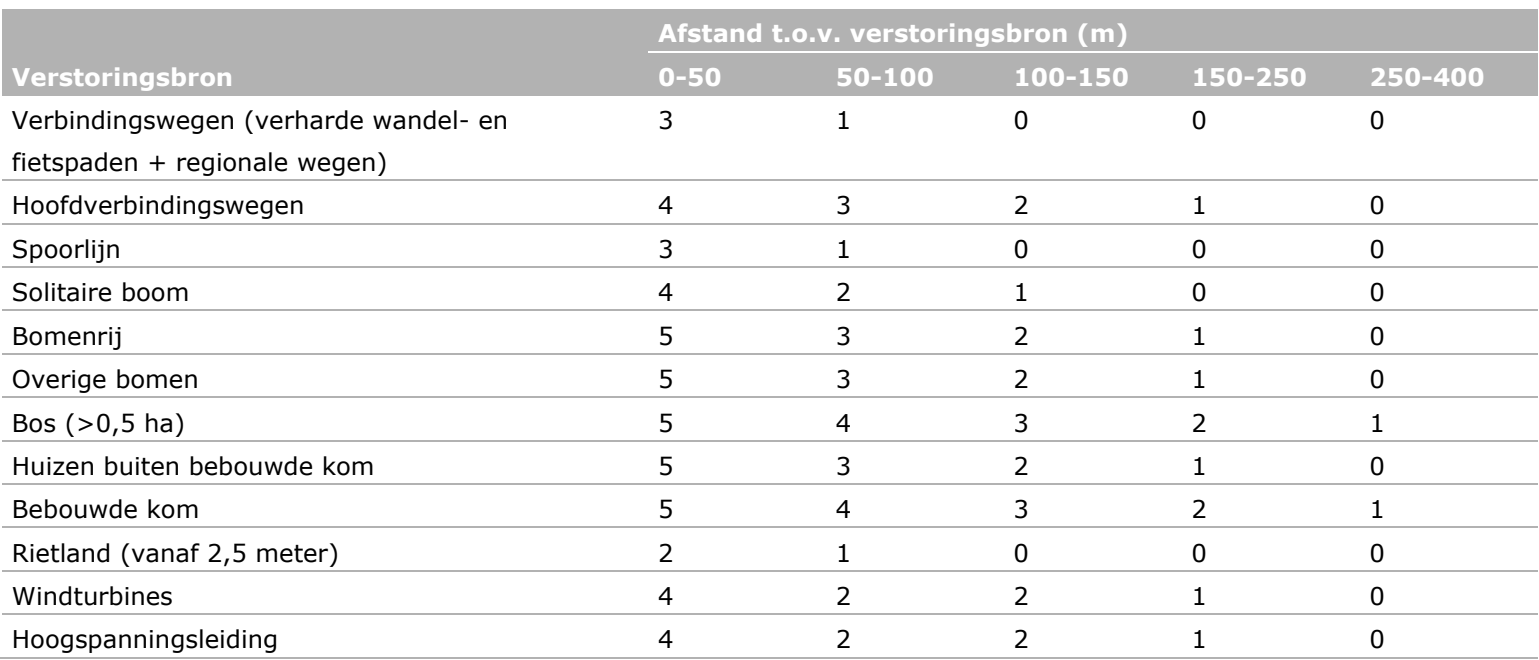

Bovenstaande werkwijze heeft geleid tot onderstaand kaartbeeld (zie Figuur 8). Op het kaartbeeld zijn de gradaties van verstoring duidelijk zichtbaar.

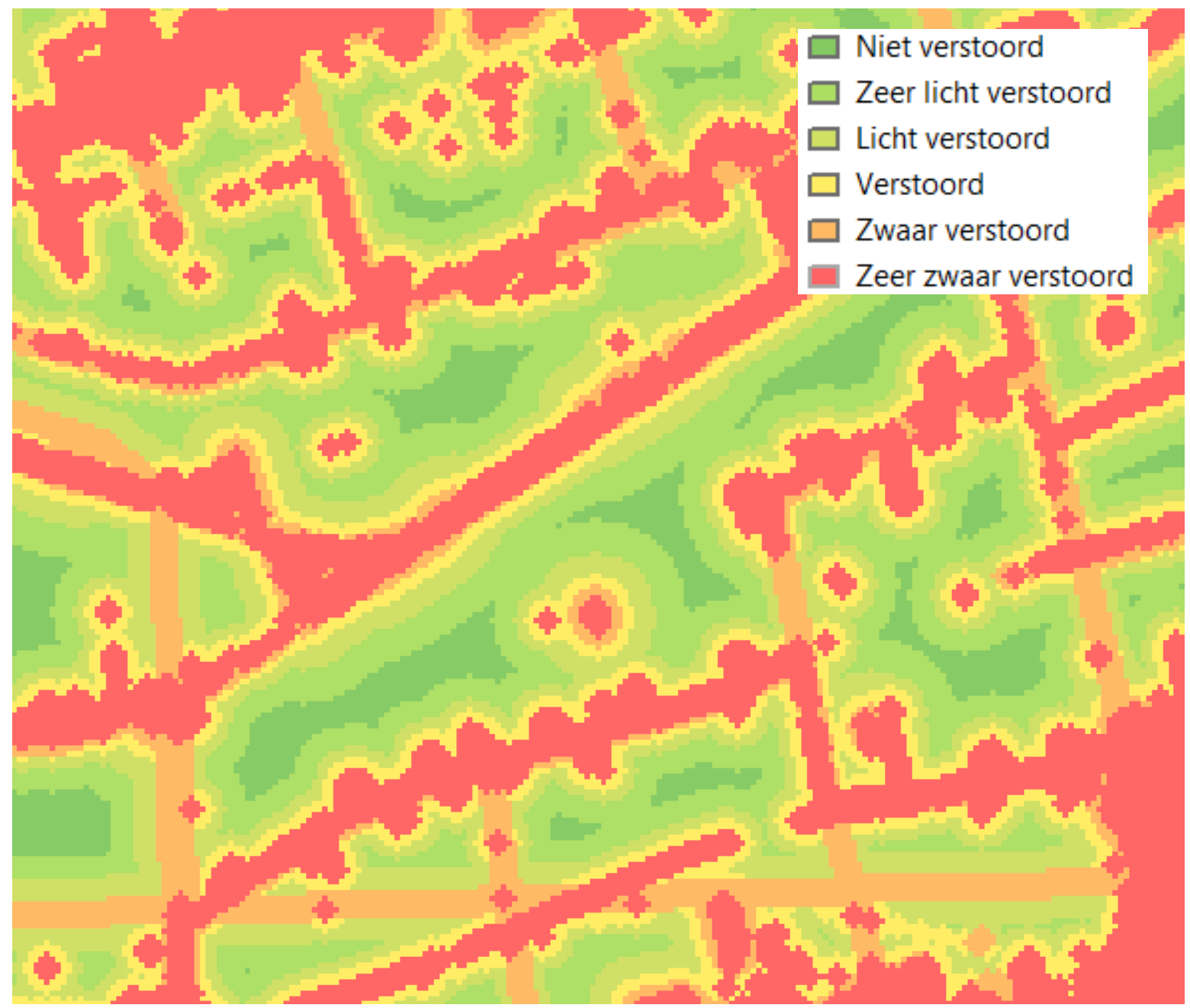

Figuur 8 Verstoring. 


\subsubsection{Update begrenzingen}

Beheer-op-Maat voert analyses uit op het niveau van deelgebieden. In beginsel zijn deze deelgebieden vrij te kiezen. Voorheen werden deze deelgebieden handmatig ingetekend in Beheer-op-Maat, op aangeven van de collectieven. Dit leidde tot incidenteel onnauwkeurige, niet praktisch hanteerbare begrenzingen (bijvoorbeeld vanwege niet samenvallen met de deelgebieden zoals in de beheerplanning en/of bij de inventarisaties wordt gehanteerd).

In 2019 is een nieuwe set aan deelgebied-begrenzingen opgenomen (+/- 500 deelgebieden, weergegeven in blauw in Figuur 9). Deze set is relevant voor weidevogels en betreft de begrenzingen van de BTS-telgebieden zoals gebruikt door de collectieven bij het uploaden van de weidevogelgegevens op de website van boerenlandvogels (ontwikkeld en beschikbaar gesteld door LandschappenNL).

De deelgebieden zijn in BoM toegekend aan de collectieven (en verbonden aan bijbehorende gebruikersaccounts) op basis van de begrenzing van de werkgebieden (zie 41 zwart omlijnde gebieden in Figuur 9).

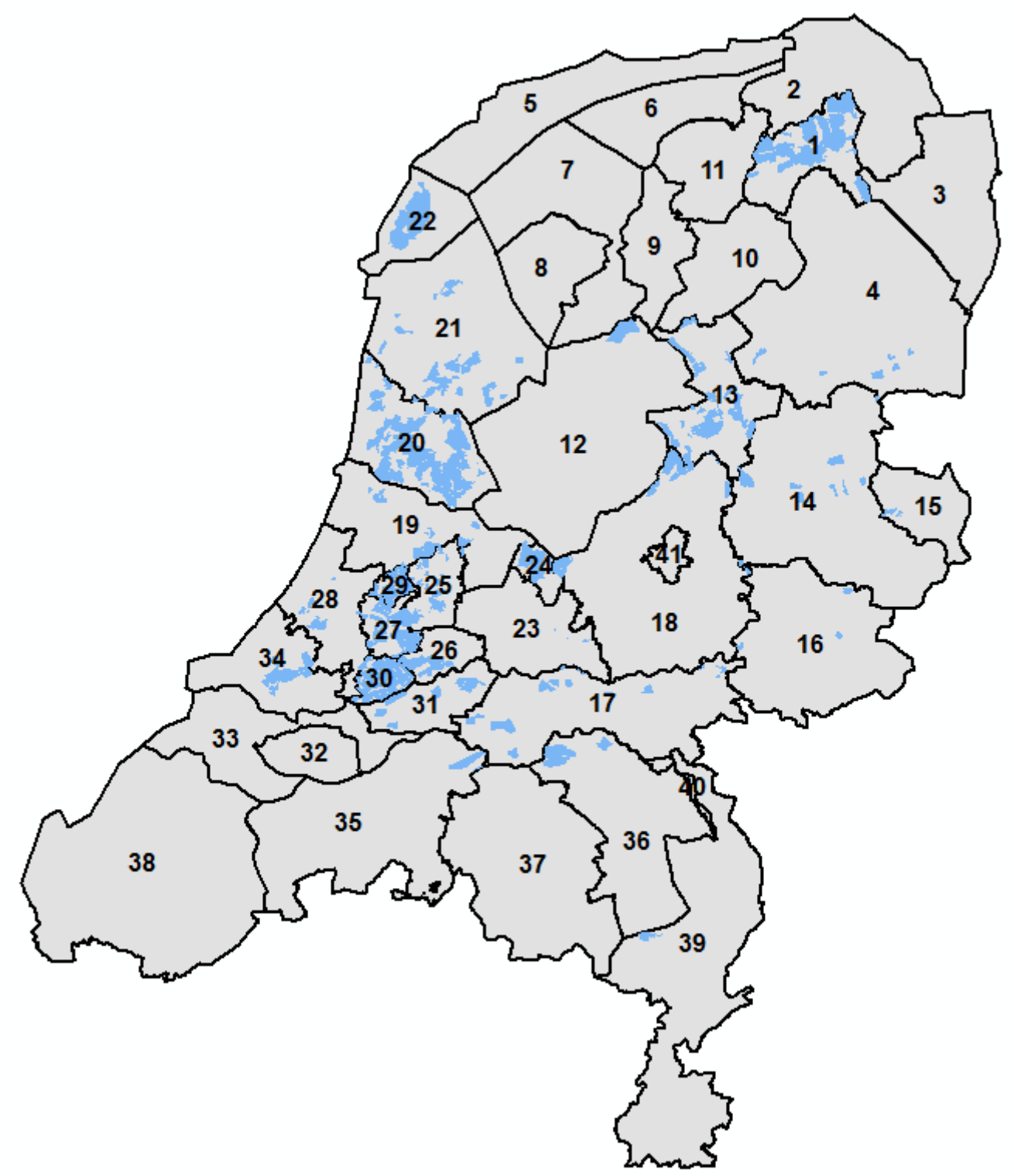

Figuur 9 Toegepaste begrenzingen. Zwarte begrenzingen betreffen de begrenzingen van de collectieven. Blauwe vlakken betreffen de BTS-telgbieden. 


\subsubsection{Vernieuwde toepassingen satellietbeelden}

\section{Herkennen graslandfasen}

De kern van weidevogelbeheer betreft in Nederland het op orde krijgen van de habitatkwaliteit in de graslanden. Eerdere ervaringen laten zien dat NDVI-satellietbeelden een belangrijke rol kunnen spelen om hier gebiedsdekkend inzicht in te krijgen. In 2019 is een onderzoek uitgevoerd - parallel aan de ontwikkelingen binnen Beheer om Maat - waarin op het vlak van een aantal onderdelen is getoetst in hoeverre deze beelden inzicht geven in de feitelijke situatie en in hoeverre ze een betrouwbaar hulpmiddel kunnen zijn bij het plannen en evalueren van weidevogelbeheer. In onderstaande tekst zijn de belangrijkste resultaten beschreven. (Zie Visser et al., 2019b voor de volledige rapportage.)

\section{Inleiding}

Waar het om de betekenis van Nederland gaat, wordt de kern van weidevogelbeheer gevormd door het op orde krijgen van de habitatkwaliteit in grasland (Wymenga et al., 2009) in gebieden die landschappelijk geschikt zijn voor weidevogels (Oosterveld et al., 2014; Van der Geld et al. 2013). Het knelpunt wordt gevormd door structuurrijke, kruidenrijke graslanden, die afgelopen decennia zeer sterk in omvang zijn verminderd (Teunissen et al., 2012; Melman et al., 2016). Ook buiten de traditionele weidevogelgebieden is sprake van een sterke afname van kruidenrijk grasland en bijbehorende biodiversiteit.

In het agrarisch natuurbeheer wordt veel aandacht besteed aan selectie van potentieel geschikte gebieden, waar vervolgens door middel van beheer wordt gestreefd naar behoud en ontwikkeling van kruidenrijk grasland. In het verleden werd een beheercontract (bv. 15 juni beheer) als indicatie gebruikt dat de habitat daarmee op orde was (Kleijn, 2012; Melman et al., 2004; 2006). Gebrek aan inzicht in de feitelijke habitatkwaliteit van graslanden was daar debet aan. Met de komst van NDVIsatellietbeelden is daar verandering in gekomen. Daarmee kunnen feitelijke, zeer actuele beelden van de graslandtoestand worden verkregen.

De NDVI geeft inzicht in de vitaliteit en biomassa van de vegetatie en wordt ingezet voor een breed scala aan doeleinden, waaronder precisielandbouw en het voorspellen en voorkomen van bosbranden. Ook vanuit ecologisch oogpunt zijn er tal van toepassingsmogelijkheden, zoals het onderscheiden van intensief en extensief gebruikte graslanden. Dit is van belang voor het in beeld krijgen van de structuur en kruidenrijkdom en daarmee de geschiktheid als habitat voor weidevogels. Sinds enkele jaren wordt in het kennissysteem voor weidevogels (Beheer-op-Maat; BoM (Visser et al., 2019c)) gebruikgemaakt van NDVI-beelden bij het in beeld brengen van de potentiële habitatkwaliteit voor weidevogels. In de online webtool is een kaart gepubliceerd die inzicht geeft in de productiviteit van het gewas. ${ }^{2}$ Deze kaart is gebaseerd op een langjarig gemiddelde van de situatie in de winter en kan worden ingezet om productieve graslanden te onderscheiden van minder productieve graslanden (zie Figuur 1).

De NDVI-beelden lijken als hulpmiddel bij het vaststellen van de feitelijke habitatkwaliteit veelbelovend, maar kalibratie en validatie zijn noodzakelijk om de betrouwbaarheid en nauwkeurigheid te kennen. Hoe hangen de NDVI-beelden samen met de situatie in het veld? Welke eigenschappen van de vegetatie kunnen uit de beelden worden afgeleid? In dit verkennende onderzoek is gekeken naar de samenhang tussen NDVI-beelden en:

1. De graslandfase ${ }^{3}$ en kruidenrijkdom

2. De structuur van de vegetatie (biomassa, structuurvariatie, doorwaadbaarheid)

Daarnaast is verkend of er een relatie bestaat tussen de verspreiding van weidevogels en de NDVIbeelden.

\footnotetext{
2 De productiviteit is de snelheid waarmee het gras groeit. Deze is hoog bij een hoge mestgift en/of droge bodem en lager bij een lage mestgift en/of vochtige bodem.

3 A.d.h.v. Schippers e.a. (2015), waarin de volgende fasen worden onderscheiden: $0=$ Engels raaigrasland, $1=$ grassenmix, 2= dominant stadium, $3=$ gras-kruidenmix, $4=$ bloemrijk grasland, $5=$ schraalland.
} 


\section{Methode}

Het onderzoek kan methodisch gezien worden opgeknipt in twee onderdelen, die beide op een andere schaal zijn uitgevoerd. Met betrekking tot de kenmerken van de vegetatie (biomassa, structuurvariatie doorwaadbaarheid en aandeel kruiden) zijn metingen verricht op 58 percelen in de Ronde Hoep, verspreid over 5 telrondes. In deze telrondes zijn tevens de locaties van weidevogels in beeld gebracht. De graslandfase is vastgesteld op 233 percelen, verspreid door Nederland.

Voor bovengenoemde percelen zijn de benodigde NDVI-data ingewonnen. Daarbij zijn zowel de volledige reeks aan NDVI-waarden meegenomen als de standaarddeviatie van de NDVI op perceelniveau. Ten slotte is voor ieder perceel het aantal maaibeurten vastgesteld op basis van het aantal plotselinge afnames van de NDVI gedurende het groeiseizoen.

Binnen de statistische analyses (variantieanalyses en -regressies) is verkend wat de relatie is tussen de NDVI-beelden (en afgeleide variabelen zoals de standaarddeviatie en het aantal maaibeurten) en de graslandfase, aandeel kruiden, doorwaadbaarheid, biomassa en structuurvariatie van de vegetatie.

Met betrekking tot de relatie tussen de NDVI-beelden en de dichtheid aan weidevogels is een verkennende (visuele) analyse verricht.

\section{Herkenning graslandfasen op basis van NDVI}

\section{Conclusie:}

De graslandfasen verschillen significant van elkaar op het vlak van meerdere parameters die zijn ontleend aan de NDVI. Vooral het winterbeeld van NDVI en het aantal maaibeurten (afgeleid uit scherpe dalingen in de NDVI) lijken indicatief voor de graslandfasen. Ook op het gebied van de standaarddeviatie van de NDVI zijn significante verschillen gevonden tussen de graslandfasen. Ondanks de significante verschillen is bij de meeste variabelen sprake van overlap tussen de verschillende graslandfasen.

\section{Aanbeveling:}

Voor een vergroting van de betrouwbaarheid van de identificatie van graslandfasen lijkt het verstandig om gebruik te maken van Random Forest-modellen, als automatische herkenning van de graslandfasen op basis van remote sensing het doel is. Dergelijke modellen kunnen alle variabelen tegelijkertijd meenemen en in onderlinge samenhang interpreteren. Mogelijk kan dit verder worden geoptimaliseerd door het model aan te vullen met andere vegetatie-indexen en afgeleiden (zowel gebaseerd op radar- als satellietbeelden).

\section{NDVI, habitatkwaliteit grasland \& weidevogels}

\section{Conclusie:}

Er zijn significante relaties tussen de NDVI-beelden en kenmerken van de vegetatie die de weidevogelhabitatkwaliteit bepalen, waaronder de doorwaadbaarheid en structuurvariatie van de vegetatie. De relatie tussen NDVI-beelden en de dichtheid aan weidevogels is tevens zeer sterk: gezinnen van zowel de kievit, tureluur als de grutto bezetten de extensiefste percelen met de hoogste dichtheden (zie Figuur 10). Eerder in het seizoen (tijdens de nestfase) geven de grutto en tureluur de voorkeur aan percelen met gemiddelde NDVI-waarden/gebruiksintensiteit. De gevonden verschillen tussen de soorten laten zich goed verklaren vanuit de verschillen in broedecologie.

\section{Aanbeveling:}

De relatie tussen de dichtheid aan weidevogels en NDVI-beelden is zeer sterk. NDVI-beelden geven daarmee een goede indicatie van de habitatkwaliteit en kunnen om deze reden worden ingezet als hulpmiddel bij het optimaliseren van het weidevogelbeheer. Dit betreft bijvoorbeeld het identificeren van geschikte locaties voor weidevogelbeheer en het monitoren en evalueren van de beheereffecten. 


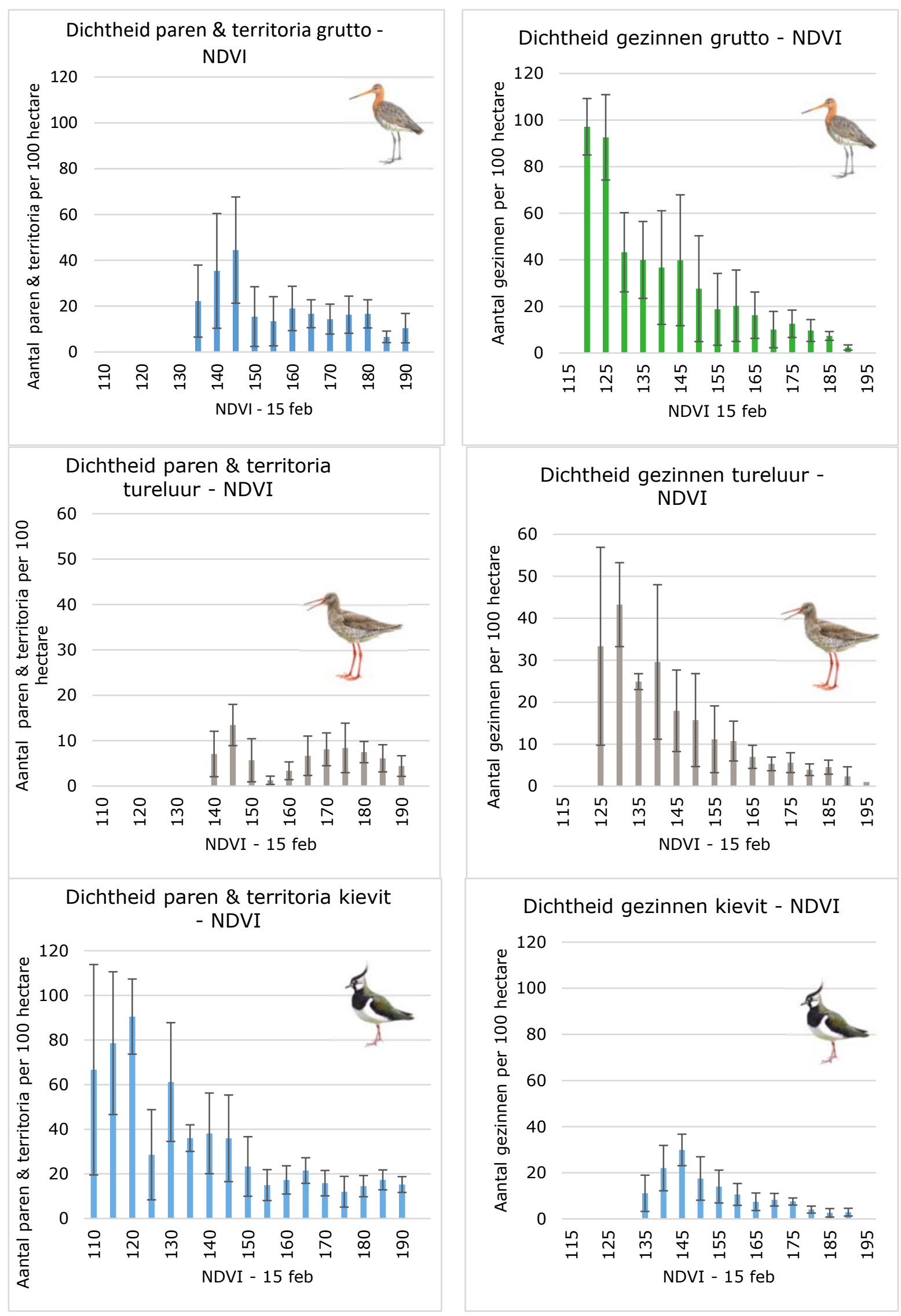

Figuur 10 Relatie tussen de NDVI en de dichtheid aan weidevogels. De linkerfiguren betreffen de relaties tussen de dichtheid aan paren en territoria in het vroege voorjaar en de NDVI. De rechterfiguren betreffen de dichtheid aan gezinnen later in het seizoen en de NDVI. 


\section{Algemeen}

De algemene conclusie is dat NDVI-beelden een bruikbaar en betrouwbaar instrument kunnen zijn om graslanden te interpreteren naar voor weidevogels relevante habitatkenmerken. De grootste kracht zit in het gebruik voor diagnostische kenmerken op gebiedsniveau: het herkennen van de gunstigste omstandigheden voor weidevogels.

Omdat NDVI-beelden bijna wekelijks worden vervaardigd, lijken ze ook interessant om realtime informatie te genereren over de ontwikkeling van de habitatgeschiktheid gedurende het seizoen. Hiermee zou een zeer krachtig instrument beschikbaar komen voor collectieven om tijdens het seizoen te kunnen bijsturen, zodat er voldoende geschikte habitat is gedurende het gehele opgroeiseizoen.

\section{Kuikenland monitor}

Uit bovengenoemd onderzoek (Visser et al., 2019b) bleek de relatie tussen de dichtheid aan weidevogels en NDVI zeer sterk te zijn. NDVI-beelden geven daarmee een goede indicatie van de habitatkwaliteit en kunnen om deze reden goed worden ingezet als hulpmiddel bij het optimaliseren van het weidevogelbeheer. Dit betreft bijvoorbeeld het identificeren van geschikte locaties voor weidevogelbeheer en het monitoren en evalueren van de beheereffecten.

Omdat NDVI-beelden ca. wekelijks worden vervaardigd, lijken ze ook interessant om realtime informatie te genereren over de ontwikkeling van de habitatgeschiktheid gedurende het seizoen. Hiermee zou een zeer krachtig instrument beschikbaar komen voor collectieven en TBO's.

Naar aanleiding van bovenstaande is gewerkt aan het concept 'kuikenlandmonitor' (zie Figuur 11 voor visualisatie). De kuikenlandmonitor vertaalt landelijke remote sensing-beelden naar voor de praktijk eenvoudige kleuren-klassen die realtime inzicht geven in de habitatkwaliteit voor weidevogels. Een dergelijke website kan een hulpmiddel zijn bij het bepalen van lastminutebeheer. Daarnaast kan het een vast onderdeel gaan vormen van de jaarlijkse evaluatie:

- Waar was gedurende het broedseizoen geschikte habitat aanwezig?

- Op welke locaties leidt het beheer tot geschikte habitat? Waar niet?

Bovenstaande vragen gaan gepaard met een andere vorm van evalueren. Tot op heden staat bij het evalueren vaak de inspanning centraal: hoeveel areaal beheerpakketten hebben wij als collectief? Zijn alle beheerafspraken nagekomen? Liggen er voldoende percelen met beheerpakketten? Bij het evalueren met behulp van een tool, zoals de kuikenlandmonitor, verschuift de focus naar de gerealiseerde habitatkwaliteit: wat is de geschiktheid van dit leefgebied voor weidevogels? Tijdens welke periode treedt een tekort aan geschikt kuikenland op? Hoe kunnen we de habitat verder optimaliseren? 

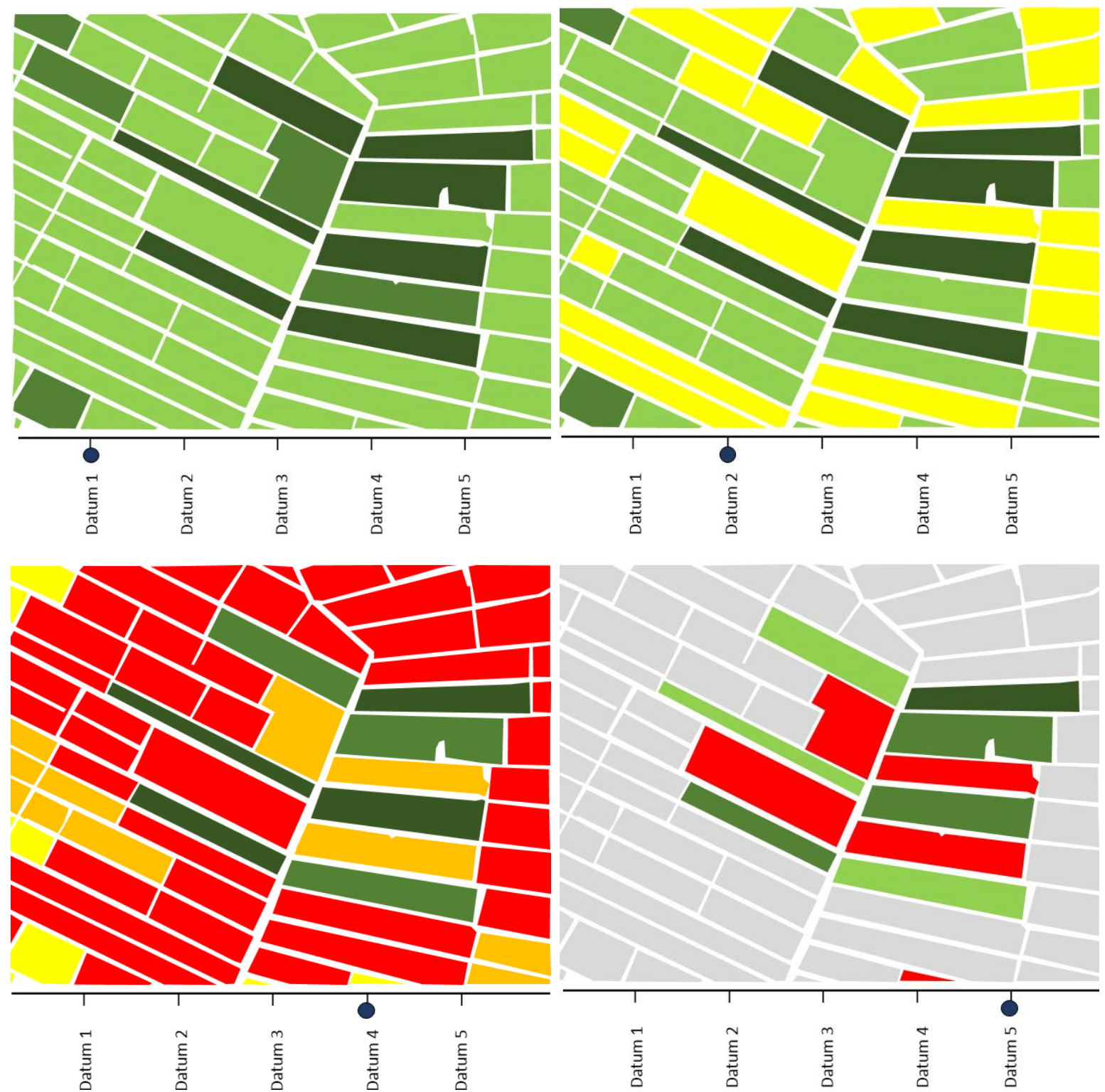

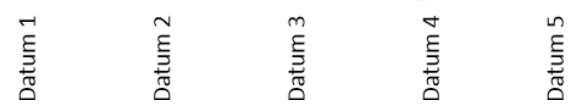

\begin{tabular}{|c|c|c|}
\hline Doorwaadbaarheid & Structuurrijkdom & Geschiktheid voor kuikens \\
\hline \multicolumn{2}{|l|}{ Recent gemaaid } & to \\
\hline Goed & Structuurrijk & \\
\hline Goed & Redelijk Structuurrijk & \\
\hline Matig & Matig structuurrijk & D. \\
\hline Matig & Structuurarm & $b-6$ \\
\hline Slecht & Structuurarm & a. \\
\hline Zeer slecht & Zeer structuurarm & $0 \Leftrightarrow 8 \mathrm{~m}$ \\
\hline
\end{tabular}

Figuur 11 Visualisatie concept 'kuikenlandmonitor'. Onderin ziet u de legenda: de kleuren staan voor de geschiktheid van het grasland als foerageerhabitat voor weidevogelgezinnen op een bepaald momenten. De vier beelden tonen de ontwikkeling van de habitatkwaliteit gedurende het seizoen. Dergelijke informatie zou op een website kunnen worden ontsloten, waarbij de gebruiker de tijdsbalk zelf kan verschuiven om zo de ontwikkeling in beeld te krijgen. Idealiter kunnen dergelijke beelden worden gecombineerd met weidevogelstippen, zodat het verband tussen verplaatsingen van weidevogels en de ontwikkeling van het habitat zichtbaar wordt. 


\subsection{Communicatie}

Gedurende de looptijd van het project is met de potentiële gebruikers en betrokkenen bij BoM contact geweest. De contactvormen liepen uiteen van gelegenheidsgesprekken, mails, telefonische consultatie tot geplande overleggen. Het gaat om leden van collectieven alsmede Boerennatuur, LandschappenNL en verschillende provincies. Deze contacten waren gericht op het zicht krijgen op behoeftes, technische ondersteuning, gebruikerservaringen, -wensen en verkennen van kansen en mogelijkheden voor verdere ontwikkeling van het kennissysteem. Daarnaast zijn er presentaties verzorgd en zijn adviezen gegeven en is er verkend welke mogelijkheden/perspectieven voor verdere samenwerking er zijn. Een overzicht van de contacten is weergegeven in onderstaande tabel.

Tabel 2 Overzicht communicatie met gebruikersgroep en projectomgeving gedurende 2019.

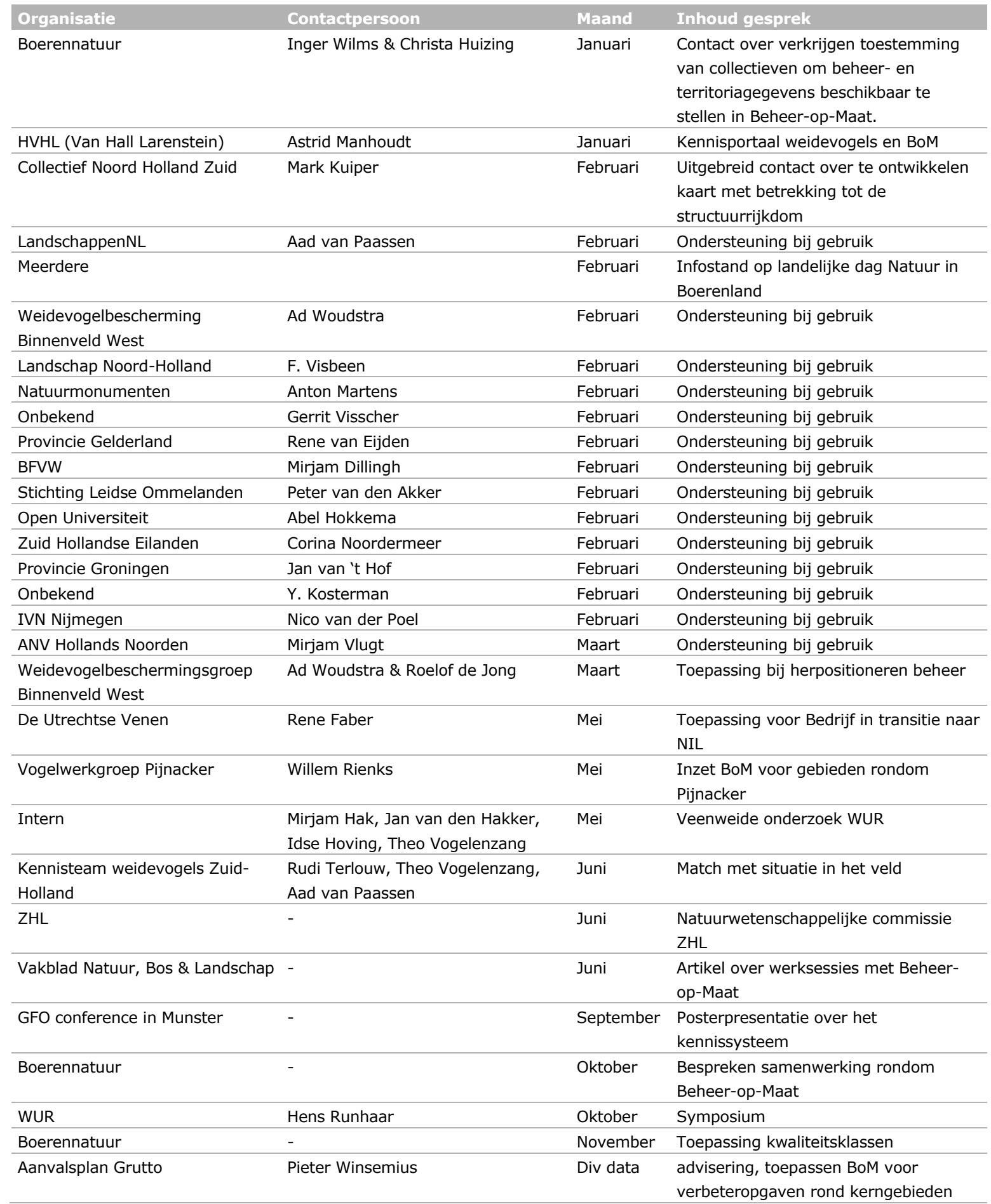




\section{Gebruikersgroep}

Al met de aanvang van dit project is aangegeven dat er behoefte is aan een gebruikersgroep rond BoM. Zo'n groep kan gestructureerd ervaringen, wensen e.d. zichtbaar maken en helpen bij het maken van keuzes en het stellen van prioriteiten. Er zijn weliswaar een paar bijeenkomsten geweest, maar de tijd was nog niet rijp voor een vaste, geïnstitutionaliseerde gebruikersgroep. In februari is wel met een brede gebruikersgroep overleg geweest, waarin ervaringen zijn gedeeld en wensen geïnventariseerd (inbreng deelgebieden, actualisering basisinfo, gebruik weidevogelstippen (inventarisatie) e.d.). De wensen zijn voor een groot deel gerealiseerd (zie paragraaf 3.3).

In goed overleg met BoerenNatuur is vastgesteld dat van de kant van de collectieven de tijd nog niet rijp was voor een vast bijeenkomstritme. Inmiddels hebben de collectieven per leefgebiedtype kenniskringen ingesteld. Deze kenniskringen lijken de geëigende fora om - wanneer daar aanleiding toe is - BoM-gerelateerde zaken te agenderen. In november 2019 is er een eerste, gezamenlijke bijeenkomst geweest van de vier kenniskringen, waarin aandacht voor habitatkwaliteit centraal stond. Daarbij is veel aandacht besteed aan BoM en wat BoM voor de collectieven kan betekenen. De reacties van de collectieven om met behulp van een hulpmiddel als BoM aandacht aan habitatkwaliteit te schenken, waren positief. Er is grote behoefte aan kennis over wat de randvoorwaarden zijn om tot een substantiële bijdrage voor duurzame populatie van doelsoorten te komen en welke inrichtings- en beheermaatregelen daarvoor nodig zijn. Het wederzijdse voornemen is om meer van dergelijke bijeenkomsten te houden. 


\title{
4 Discussie
}

\author{
Resultaten \\ Voor het leefgebiedtype open grasland zijn de kentallen voor het weidevogelbeheer operationeel \\ gemaakt. Daarmee is het mogelijk voor een bepaald gebied zowel de weidevogelkwaliteiten als de \\ potentiële en gerealiseerde habitatkwaliteit en daarmee de verbeteropgave te bepalen. Dit \\ beschouwen wij als een belangrijke mijlpaal, waar we een aantal jaren naar hebben toegewerkt. De \\ kentallen kunnen een belangrijk houvast zijn bij het maken en evalueren van beheerplannen. \\ Tegelijkertijd vormen ze ook een goed handvat om gebieden met elkaar te vergelijken en daarmee \\ van elkaar te leren. Als belangrijkste toepassing op dit vlak zien we vooralsnog het doen van \\ gezamenlijke sessies (verschillende gebieden, verschillende collectieven). Daarmee zal gaandeweg de \\ betekenis en de zeggingskracht van de verschillende kentallen blijken.
}

$\mathrm{Er}$ is een stevig begin gemaakt met het uitbreiden van BoM naar andere leefgebiedtypen dan 'open grasland'. Dat is ecologisch-inhoudelijk een grote uitdaging gebleken. De kennis van veel soorten van die leefgebiedtypen is veelal minder ver ontwikkeld dan voor weidevogels, waar het gaat om de kwantificering van de randvoorwaarden van de habitateisen. Het is lastig gebleken om de verbeteropgaven in systematische, gekwantificeerde en geïntegreerde vorm vast te stellen. Ook is het niet altijd mogelijk de verbeteropgaven in concrete beheermaatregelen (welke maatregelen op wel ruimtelijke schaal) te vertalen. Een positief punt van het werken met een kennissysteem als BoM is wel dat het dwingt om alle habitatonderdelen systematisch na te lopen. Het signaleren van kennishiaten kan als voeding worden gebruikt voor programmering van nieuwe onderzoeksactiviteiten.

De verfijning en actualisering van kaartlagen geven een veel betere aansluiting op de praktijk. De verfijning van de weergave van de vochtsituatie met behulp van de kwelgegevens geeft een veel genuanceerder beeld op lokaal niveau, wat ook direct door gebruikers werd herkend en positief gewaardeerd. Dit type verbeteringen komt het draagvlak voor gebruik van BoM ten goede.

\section{Vernieuwde toepassingen met gebruikmaking van de groenindex (NDVI)}

Gebleken is dat NDVI-beelden goed kunnen worden gebruikt bij het bepalen van graslandeigenschappen die relevant zijn voor de habitatkwaliteit voor weidevogels. De eerste kalibratie ziet er in ieder geval veelbelovend uit. Mogelijk kunnen in de toekomst NDVI-beelden rechtstreeks worden gebruikt ter bepaling van de actuele habitatkwaliteit en hoeven beheerpakketten als proxy niet langer te worden gebruikt. Gebruikmaking van NDVI-beelden, die ongeveer wekelijks worden vervaardigd, geeft ook de mogelijkheid van realtime inzicht in de habitatkwaliteit. Daarmee ontstaat de mogelijkheid om actueel inzicht te krijgen in omvang en ruimtelijke spreiding van het kuikenlandaanbod. In combinatie met actuele gegevens over aanwezigheid van weidevogelgezinnen kan dergelijke info worden gebruikt voor lastminutebeheer. Collectieven blijken in dergelijke informatie zeer geïnteresseerd te zijn.

\section{Communicatie}

Het belang van contact houden met de gebruikersgroep is groot. Alleen bij voldoende draagvlak zal het model voor de praktijk betekenis krijgen. Bij het contact houden met de gebruikers is het een opgave om de agendering van het overleg zo te timen dat het bij alle betrokkenen gelijke urgentie heeft. Bij de start van het ANLb moesten collectieven veel aandacht aan organisatorische en administratieve zaken geven en was er betrekkelijk weinig ruimte voor ecologisch-inhoudelijke zaken en het productief meedenken met de ontwikkeling van BoM. Met het starten van de kenniskringen voor de verschillende leefgebiedtypen door BoerenNatuur is daar verandering in gekomen. In de kenniskringen is het corebusiness om na te denken over vergroting van de habitatkwaliteit. Kennissystemen als BoM kunnen daarbij nuttig zijn. Idealiter kunnen deze kenniskringen een grote rol krijgen bij het maken van keuzes en het stellen van prioriteiten bij de verdere ontwikkeling van het kennissysteem. 


\section{Status BoM}

BoM is stap voor stap ontwikkeld, als hulpmiddel om tot betere beheerplannen te komen in het agrarisch natuurbeheer. Getracht is daarbij alle relevante wetenschappelijke kennis te benutten en om een breed draagvlak te krijgen bij alle betrokkenen van het agrarisch natuurbeheer. De verschillende rapporten die de afgelopen jaren zijn uitgebracht, beschrijven de zoektocht die is afgelegd. Het gebruik van BoM is vrijwillig; het staat de collectieven vrij om BoM wel of niet te benutten. De fase waarin het agrarisch natuurbeheer zich nu bevindt, is er een van toenemende professionalisering van de collectieven. De eerder aangestipte oprichting van de kenniskringen voor de leefgebiedtypen is daar een voorbeeld van. Vanuit de kenniskringen en BoerenNatuur zien we een groeiende interesse om van BoM gebruik te maken. We denken dat de gezamenlijke betrokkenheid van onderzoekers en beheerders bij de verdere ontwikkeling van BoM een goede zaak, of zelfs noodzakelijk is. Daarmee kan het vertrouwen in de science based output van BoM bij de collectieven groeien en houden wetenschappers voeling met de bruikbaarheid voor de praktijk en wat nieuwe wensen en prioriteiten daarin zijn. De collectieven kunnen resultaten van BoM gebruiken om onderling hun gebieden, beheerinzet en ecologische effecten met elkaar te vergelijken en daarvan te leren (lerend beheer). Tevens kan deze output door hen ook worden gebruikt bij het afleggen van verantwoording aan de maatschappij (bv. door resultaten op te nemen in het jaarverslag). De kentallen zoals die nu voor het weidevogelbeheer beschikbaar zijn, geven als het ware een helikopterview, die uitwisseling van ervaringen zeer goed mogelijk maakt. 


\section{Conclusies en aanbevelingen}

In dit project is BoM op een aantal punten verbeterd en uitgebreid. Zo zijn de eerder geconcipieerde kentallen voor weidevogelbeheer in BoM operationeel gemaakt, een belangrijke mijlpaal om voor gebieden weidevogelkwaliteiten en potentiële en gerealiseerde habitatkwaliteit weer te geven. Er is een begin gemaakt met de uitbreiding van BoM naar andere leefgebiedtypen dan open grasland. Voor een aantal gidssoorten (o.a. Patrijs en Grauwe kiekendief) is een habitatkwaliteitssystematiek ontwikkeld, waarmee kaarten kunnen worden gemaakt die de habitatkwaliteit weergeven. In een vervolg kunnen dergelijke concepten operationeel worden gemaakt.

Binnen BoM-weidevogels is voorts een aantal kaartlagen geactualiseerd en verfijnd (openheid, bodemvochtigheid, verstoring en zwaarte gewas). Hierdoor is de bruikbaarheid voor de praktijk sterk toegenomen. $\mathrm{Er}$ is een nieuwe set aan gebiedsbegrenzingen toegevoegd die overeenkomt met de BTStelgebieden die LandschappenNL hanteert. Daarmee kunnen voor deze, voor de beheerders relevante, gebieden evaluaties worden gedaan.

Voor de NDVI-beelden is een bescheiden kalibratie uitgevoerd. Deze laat zien dat er een duidelijke samenhang is tussen NDVI en graslandtype, waarmee vervolgens de weidevogeldichtheid sterk samenhangt. NDVI en habitatkwaliteit hangen daarmee aantoonbaar samen. Hiermee komen nieuwe, interessante toepassingsmogelijkheden voor NDVI in zicht, namelijk het vaststellen van habitatkwaliteit, los van het ter plekke heersende beheerregime.

Tijdens het uitvoeren van het project is contact geweest met diverse stakeholders gericht op het zicht krijgen van hun gebruikerservaringen en -wensen, teneinde de relevantie van BoM voor de praktijk zo groot mogelijk te doen zijn. De nu uitgevoerde werkzaamheden aan BoM sluiten daar zo goed mogelijk op aan. Positief is de groeiende interesse van collectieven in het gericht en onderbouwd versterken van de habitatkwaliteit. BoM kan daarin een belangrijke rol spelen.

Een project als dit stond in het teken van het onderhoud aan BoM en het verder aanpassen om zowel wetenschappelijk als ICT-technisch up-to-date te zijn en zo goed mogelijk op de wensen van gebruikers aan te sluiten. Dat is allesbehalve afgerond. Voor weidevogels is het systeem inhoudelijk en qua gebruikersvriendelijkheid functioneel. Daarvoor is de tijd rijp om het systeem in de praktijk volop te gebruiken: voor het kritisch kijken naar de landschappelijke kenmerken in het eigen gebied, naar de lokalisatie, omvang en aard (zwaarte) van de beheerinspanningen. De bevindingen in eigen gebied kunnen worden gelegd naast die in andere gebieden, zodat systematisch kan worden vormgegeven aan lerend beheer. Hiervoor bieden de operationeel geworden kentallen een goed houvast.

Voor de andere leefgebiedtypen staat het kennissysteem pas aan het begin. Voor een aantal gidssoorten zijn de habitatseisen en bottleneckfactoren gekwantificeerd en is het concept uitgewerkt hoe het in BoM zou kunnen worden opgenomen. Het relateren aan beheermaatregelen is in veel gevallen weerbarstiger dan in open grasland. Ook is er sprake van hiaten in de ecologische kennis van de doelsoorten. Ondanks deze onvolkomenheden, of misschien wel dankzij, is het werken aan het kennissysteem belangrijk. Immers, van de collectieven wordt verwacht dat zij met hun beheeractiviteiten bijdragen aan versterking van de populaties van de doelsoorten. Dus waar het aan dergelijke kennis ontbreekt, moet daaraan worden gewerkt. Het verder ontwikkelen van het kennissysteem kan daarmee een belangrijke impuls geven aan nieuw onderzoek. 


\section{Literatuur}

Bransby, D.I., \& Tainton, N.M. (1977). The disc pasture meter: possible applications in grazing management. Proceedings of the annual congresses of the Grassland Society of Southern Africa, 12(1), 115-118.

Karl, M.G., \& Nicholson, R.A. (1987). Evaluation of the forage-disk method in mixed-grass rangelands of Kansas. Journal of Range Management, 467-471.

Kleijn, D. (2012). De effectiviteit van agrarisch natuurbeheer. Alterra, Centrum voor Ecosystemen.

Melman, T.C., Teunissen, W.A., \& Guldemond, J.A. (2016). Weidevogels-op weg naar kerngebieden. In Agrarisch natuurbeheer in Nederland: Principes, resultaten en perspectieven (pp. 137-161). Wageningen Academic Publishers.

Melman, T.C., Schotman, A.G.M., \& Hunink, S. (2004). Evaluatie weidevogelbeleid. Achtergronddocument bij Natuurbalans, 1574-0935.

Melman, T.C., Schotman, A.G.M., Hunink, S., \& de Snoo, G.R. (2006). Evaluatie weidevogelbeheer met een grutto-mozaïekmodel. De Levende Natuur, 107(3), 141-145.

Melman, D., Visser, T., \& Staritsky, I. (2018). Rapportage werkzaamheden kennissysteem BoM 2017 (No. 2865). Wageningen Environmental Research.

Oosterveld, E.B., L.W. Bruinzeel \& E. Wymenga (2014). Ecologie van weidevogels: kennisbundeling voor bescherming en beheer. A\&W-rapport 1831. Altenburg \& Wymenga ecologisch onderzoek, Feanwâlden

Paruelo, J.M., Epstein, H.E., Lauenroth, W.K., \& Burke, I.C. (1997). ANPP estimates from NDVI for the central grassland region of the United States. Ecology, 78(3), 953-958

Schotman, A.G.M., Melman, T.C.P., Ringrose, J., Meeuwsen, H.A.M., Vanmeulebrouk, B., \& Nieuwenhuizen, W. (2015). Beheer op Maat, op weg naar lerend beheer voor weidevogels (No. 2643). Alterra, Wageningen-UR.

Schippers, W., Bax, I., \& Gardeniers, M. (2015). Ontwikkelen van kruidenrijk grasland.

Teunissen, W., Schotman, A.G.M., Bruinzeel, L., ten Holt, H., Oosterveld, E., Wymenga, E., \& Melman, D. (2012). Op naar kerngebieden voor weidevogels in Nederland: werkdocument met randvoorwaarden en handreiking (No. 2012/21). Alterra, Wageningen-UR.

Van der Geld, J., \& en Ron van 't, N.G. (2013). Weidevogels in een veranderend landschap. Meer kleur in het grasland. KNNV Uitgeverij Utrecht.

Visser, T., H.A.M Meeuwsen \& Th.C.P. Melman (2019a). MNP-(Model for Nature Policy) Agrarisch; Uitwerking voor scenario's uit de Natuurverkenning 2020. Wageningen, Wettelijke Onderzoekstaken Natuur \& Milieu, WUR. WOt-technical report 159. 64 blz.; 19 fig.; 1 tab; 16 ref; 7 Bijlagen.

Visser, T., M. Kuiper, Th.C.P. Melman, (2019b). Herkennen habitatkwaliteit graslanden o.b.v. NDVI. Wageningen, Wageningen Environmental Research, Rapport 2977. 30 blz.; 9 fig.; 2 tab.; 17 ref.

Visser, T., Melman, D., \& Staritsky, I. (2019c). Rapportage werkzaamheden kennissysteem Beheerop-Maat 2018 (No. 2927). Wageningen Environmental Research.

Wang, J., Rich, P.M., Price, K.P., \& Kettle, W.D. (2005). Relations between NDVI, grassland production, and crop yield in the central Great Plains. Geocarto International, 20(3), 5-11.

Wymenga, E., Foppen, R., Melman, T.C.P., \& de Snoo, G.R. (2009). Prioriteitstelling onderzoeksvragen weidevogels. Alterra.

Zambatis, N., Zacharias, P.J.K., Morris, C.D., \& Derry, J.F. (2006). Re-evaluation of the disc pasture meter calibration for the Kruger National Park, South Africa. African Journal of Range and Forage Science, 23(2), 85-97. 
Onderstaande tabel geeft een overzicht van de belangrijkste rapporten omtrent de ontwikkeling van het kennissysteem Beheer-op-Maat. Alle rapporten zijn te downloaden door de link uit de kolom 'download' te kopiëren in de adresbalk van een webbrowser.

\begin{tabular}{|c|c|c|}
\hline Jaar & Referaat & Download \\
\hline 2019 & $\begin{array}{l}\text { Visser, T., Melman, D., \& Staritsky, I. (2019c). Rapportage } \\
\text { werkzaamheden kennissysteem Beheer-op-Maat } 2018 \text { (No. 2927). } \\
\text { Wageningen Environmental Research. }\end{array}$ & http://edepot.wur.nl/468195 \\
\hline 2017 & $\begin{array}{l}\text { Melman, Th.C.O, A.G.M. Schotman, B. Vanmeulebrouk, } \\
\text { I. Staritsky, H.A.M. Meeuwsen, 2017. Kennissysteem agrarisch } \\
\text { natuurbeheer: aandacht voor inpasbaarheid en validatie. } \\
\text { Wageningen, Wageningen Environmental Research, Rapport } \\
\text { 2791. } 66 \text { blz.; } 32 \text { fig.; } 1 \text { tab; } 16 \text { ref. }\end{array}$ & http://edepot.wur.nl/408667 \\
\hline 2017 & $\begin{array}{l}\text { Melman, Th.C.P. \& H. Sierdsema, 2017. Weidevogelscenario's: } \\
\text { Mogelijkheden voor aanpak van verbetering van de } \\
\text { weidevogelstand in Nederland. Wageningen, Wageningen } \\
\text { Environmental Research, Rapport } 2796.30 \text { blz.; } 3 \text { fig.; } 12 \text { tab.; } \\
18 \text { ref. }\end{array}$ & $\begin{array}{l}\text { http://library.wur.nl/WebQuery/wurpubs/f } \\
\text { ulltext/417827 }\end{array}$ \\
\hline 2014 & $\begin{array}{l}\text { Th.C.P. Melman, H. Sierdsema, R. Buij, G. Roerink, H. ten Holt, } \\
\text { S. Martens, H.A.M. Meeuwsen, A.G.M Schotman, 2014, Uitwerking } \\
\text { kerngebieden weidevogels; -peiling draagvlak bij provincies; - } \\
\text { verbreding kennissysteem BoM. Wageningen, Alterra Wageninen } \\
\text { UR (University \& Research centre), Alterra-rapport 2564, } 84 \text { blz.; } \\
16 \text { fig.; } 21 \text { tab.; } 49 \text { ref. }\end{array}$ & http://edepot.wur.nl/317059 \\
\hline 2012 & $\begin{array}{l}\text { Teunissen, W.A., A.G.M. Schotman, L.W. Bruinzeel, H. ten Holt, } \\
\text { E.O. Oosterveld, H. H. Sierdsema, E. Wymenga en Th.C.P. } \\
\text { Melman, 2012. Op naar kerngebieden voor weidevogels in } \\
\text { Nederland. Werkdocument met randvoorwaarden en handreiking. } \\
\text { Wageningen, Alterra, Alterra-rapport 2344. Nijmegen, Sovon } \\
\text { Vogelonderzoek Nederland, Sovon-rapport 2012/21, Feanwâlden, } \\
\text { Altenburg \& Wymenga ecologisch onderzoek, A\&W- rapport } 1799 . \\
144 \text { blz.; } 63 \text { fig.; 22tab.; } 76 \text { ref. }\end{array}$ & $\begin{array}{l}\text { http://library.wur.nl/WebQuery/wurpubs/f } \\
\text { ulltext/240248 }\end{array}$ \\
\hline 2011 & $\begin{array}{l}\text { Meeuwsen, H.A.M. \& R. Jochem (2011). Openheid van het } \\
\text { landschap; Berekeningen met het model Viewscape. Wageningen, } \\
\text { Wettelijke Onderzoekstaken Natuur \& Milieu, WOt-werkdocument } \\
\text { 281. } 74 \text { blz. } 31 \text { fig.; } 5 \text { tab.; } 8 \text { ref.; } 4 \text { bijl. }\end{array}$ & $\begin{array}{l}\text { http://library.wur.nl/WebQuery/edepot/42 } \\
221\end{array}$ \\
\hline 2011 & $\begin{array}{l}\text { Bruinzeel, L.W. \& A.G.M. Schotman } 2011 \text {. Onderbouwing } \\
\text { verstoringsafstanden weidevogels Fryslân. A\&W } \\
\text { rapport.1624/Alterra } 2184 \text { Altenburg \& Wymenga ecologisch } \\
\text { onderzoek, Feanwâlden/Alterra Wageningen }\end{array}$ & http://edepot.wur.nl/240248 \\
\hline 2009 & $\begin{array}{l}\text { Kleijn, D., Lamers, L. P. M., van Kats, R. J. M., Roelofs, J. G. M., \& } \\
\text { van 't Veer, R. (2009). Ecologische randvoorwaarden voor } \\
\text { weidevogelsoorten in het broedseizoen: resultaten van een } \\
\text { pilotstudie in het Wormer- en Jisperveld (No. 2009/dk113). } \\
\text { Directie Kennis, Ministerie van Landbouw, Natuur en } \\
\text { Voedselkwaliteit. }\end{array}$ & $\begin{array}{l}\text { http://library.wur.nl/WebQuery/wurpubs/w } \\
\text { ever/379748 }\end{array}$ \\
\hline
\end{tabular}




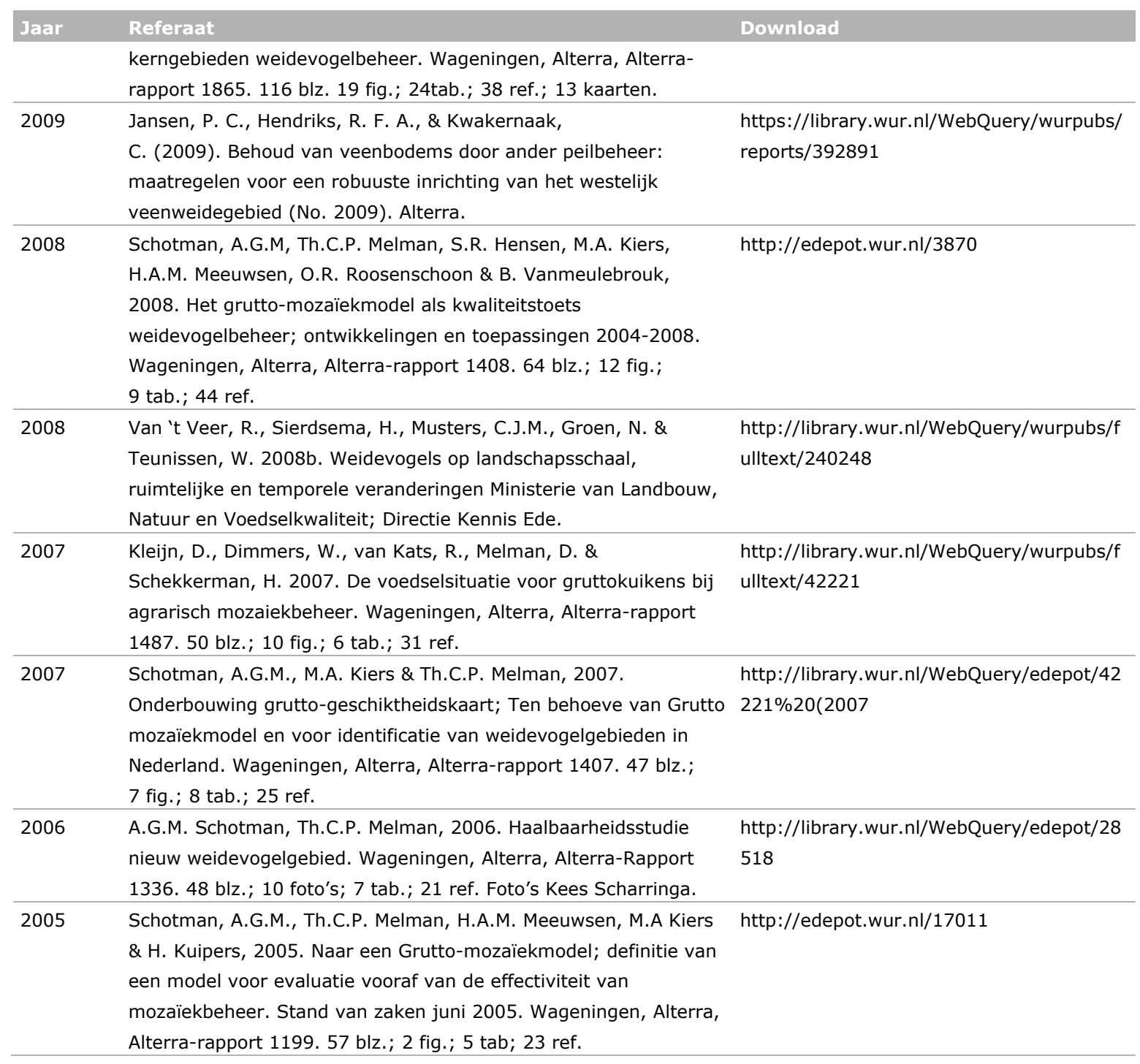

Onderstaande bronnen zijn gebruikt bij het bepalen van de rekenregels en rekenwaarden in Beheerop-Maat:

(1) E. B., Terwan, P., Guldemond, J. A., \& Paassen, A. G. (2007). Mozaïekbeheer voor weidevogels: evaluatie en mogelijkheden voor optimalisering. Ministerie van Landbouw, Natuur en Voedselkwaliteit, Directie Kennis.

(2) Boerennatuur.nl. (2017). Overzicht beheerpakketten Agrarisch Natuur- \& Landschapsbeheer, versie 1.6 (Beheerjaar 2017)

(3) Deru, J., Eekeren, N. V., \& Lenssinck, F. Mest voor weidevogelgebieden in veenweiden: dikke fractie gescheiden drijfmest is alternatief voor ruige mest. $V$-focus: vakblad voor adviseurs in de dierlijke sector, 28-30.

(4) van Eekeren, N., Bommelé, L., Bloem, J., Schouten, T., Rutgers, M., de Goede, R., ... \& Brussaard, L. (2008). Soil biological quality after 36 years of ley-arable cropping, permanent grassland and permanent arable cropping. applied soil ecology, 40(3), 432-446.

(5) Kleijn, D., Berendse, F., Verhulst, J., Roodbergen, M., Klok, T. C., \& van't Veer, R. (2008). Ruimtelijke dynamiek van weidevogelpopulaties in relatie tot de kwaliteit van de broedhabitat. Welke factoren beïnvloeden de vestiging van weidevogels? (No. 1579). Directie Kennis, Ministerie van Landbouw, Natuur en Voedselkwaliteit.

(6) Schekkerman, H., \& Beintema, A. J. (2007). Abundance of invertebrates and foraging success of Black-tailed Godwit Limosa limosa chicks in relation to agricultural grassland management. Ardea, 95(1), 39-54.

(7) Kleijn, D., Dimmers, W. J., van Kats, R. J. M., Melman, T. C. P., \& Schekkerman, H. (2007). De voedselsituatie voor gruttokuikens bij agrarisch mozaïekbeheer (No. 1487). Alterra. 
(8) Visser, T., Melman, D., Buij, R., \& Schotman, A. (2017). Greppel plas-dras voor weidevogels: betekenis als habitatonderdeel voor weidevogelkuikens (No. 2845). Wageningen Environmental Research.

(9) Kruk, M., Noordervliet, M. A. W., \& Ter Keurs, W. J. (1997). Survival of black-tailed godwit chicks Limosa limosa in intensively exploited grassland areas in The Netherlands. Biological Conservation, 80(2), 127-133.

(10) Oosterveld, E.B. (MS). Habitat use by Black-tailed Godwit chicks Limosa limosa with agricultural mosaic management in Fryslân (The Netherlands), with special reference to grazing and herb richness. Manuscript.

(11) Nijland, F. (2007). Resultaten Innovatieve monitoring 2005-2007. Weidevogelmeetnet Friesland, Leeuwarden.

(12) Terwan, P., Oosterveld, E.B., de Ruiter, H. \& Guldemond, J.A. (2003). Beheersmozaïeken voor de Grutto. Opzet van de experimenten met optimaal Gruttobeheer in zes gebieden in Noord- en West-Nederland in het kader van het project 'Nederland- Gruttoland'. Paul Terwan onderzoek \& advies, Utrecht, Altenburg \& Wymenga ecologisch onderzoek, Veenwouden/CLM Onderzoek en Advies, Utrecht.

(13) Schekkerman, H., \& Müskens, G. J. D. M. (2000). Produceren Grutto's Limosa limosa in agrarisch grasland voldoende jongen voor een duurzame populatie. Limosa, 73, 121-134.

(14) Schekkerman, H., Teunissen, W., \& Oosterveld, E. (2009). Mortality of Black-tailed Godwit Limosa limosa and Northern Lapwing Vanellus vanellus chicks in wet grasslands: influence of predation and agriculture. Journal of Ornithology, 150(1), 133.

(15) Kruk, M., Noordervliet, M. A. W., \& Ter Keurs, W. J. (1997). Survival of black-tailed godwit chicks Limosa limosa in intensively exploited grassland areas in The Netherlands. Biological Conservation, 80(2), 127-133.

(16) Nijland, F. (2007). Resultaten Innovatieve monitoring 2005-2007. Weidevogelmeetnet Friesland, Leeuwarden.

(17) Buker, J. B., \& Winkelman, J. E. (1987). Eerste resultaten van een onderzoek naar de broedbiologie en het terreingebruik van de grutto in relatie tot het graslandbeheer. Directie Beheer Landbouwgronden.

(18) Schekkerman, H. (1997). Graslandbeheer en groeimogelijkheden voor weidevogelkuikens (No. 292). DLO-Instituut voor Bos-en Natuuronderzoek.

(19) Sikkema, M. \& van Lierop, S. (2007). De functie van onbemeste graslandranden voor weidevogels in de broedtijd. Studentenverslag Hogeschool Van Hall/Larenstein, Velp.

(20) Green, R. E. (1986). The management of lowland wet grassland for breeding waders. Chief Scientist's Directorate, N 626. Nature Conservancy Council, Peterborough.

(21) Galbraith, H. (1988). Effects of agriculture on the breeding ecology of lapwings Vanellus vanellus. Journal of applied ecology, 487-503.

(22) Blomqvist, D., \& JOHANSSON, O. C. (1995). Trade-offs in nest site selection in coastal populations of Lapwings Vanellus vanellus. Ibis, 137(4), 550-558.

(23) Redfern, C.P.F. (1982) Lapwing nest sites and chick mobility in relation to habitat. Bird Study, 29, 201-208.

(24) Schekkerman, H., Teunissen, W., \& Oosterveld, E. (2005). Broedsucces van grutto's bij agrarisch mozaïekbeheer in 'Nederland gruttoland' (No. 1291). Alterra

(25) Huijsmans, J. F. M., Schröder, J. J., Vermeulen, G. D., De Goede, R. G. M., Kleijn, D., \& Teunissen, W. A. (2008). Emissiearme mesttoediening: ammoniakemissie, mestbenutting en nevenaspecten. B.V. Wageningen.

(26) Oosterveld, E. B., Kleijn, D., \& Schekkerman, H. (2008). Ecologische kenmerken van weidevogeljongen en de invloed van beheer op overleving. Kennisoverzicht en effectiviteit van maatregelen (No. 2008/090). Directie Kennis, Ministerie van Landbouw, Natuur en Voedselkwaliteit

(27) Teunissen, W., Willems, F., \& Majoor, F. (2007). Broedsucces van de Grutto in drie gebieden met verbeterd mozaïekbeheer. Beek-Ubbergen, The Netherlands: SOVON Vogelonderzoek Nederland.

(28) Wiersma P., H.J. Ottens, M.W. Kuiper, A. E. Schlaich, R.H.G. Klaassen, O. Vlaanderen, M. Postma \& B.J. Koks. 2014. Analyse effectiviteit van het akkervogelbeheer in provincie Groningen. Rapport Stichting Werkgroep Grauwe Kiekendief, Scheemda.

(29) Verstegen K. \& Sloothaak. 2012. Pilotproject: Maatregelen voor kievit op bouwland 2012. 'Kansen voor de kievit'. Coördinatiepunt Landschapsbeheer \& AP Natuuradvies, S.L 
Wageningen Environmental Research Postbus 47

6700 AA Wageningen

T 0317480700

www.wur.nl/environmental-research

Wageningen Environmental Research Rapport 3012

ISSN 1566-7197
De missie van Wageningen University \& Research is 'To explore the potential of nature to improve the quality of life'. Binnen Wageningen University \& Research bundelen Wageningen University en gespecialiseerde onderzoeksinstituten van Stichting Wageningen Research hun krachten om bij te dragen aan de oplossing van belangrijke vragen in het domein van gezonde voeding en leefomgeving. Met ongeveer 30 vestigingen, 5.000 medewerkers en 12.000 studenten behoort Wageningen University \& Research wereldwijd tot de aansprekende kennisinstellingen binnen haar domein. De integrale benadering van de vraagstukken en de samenwerking tussen verschillende disciplines vormen het hart van de unieke Wageningen aanpak. 



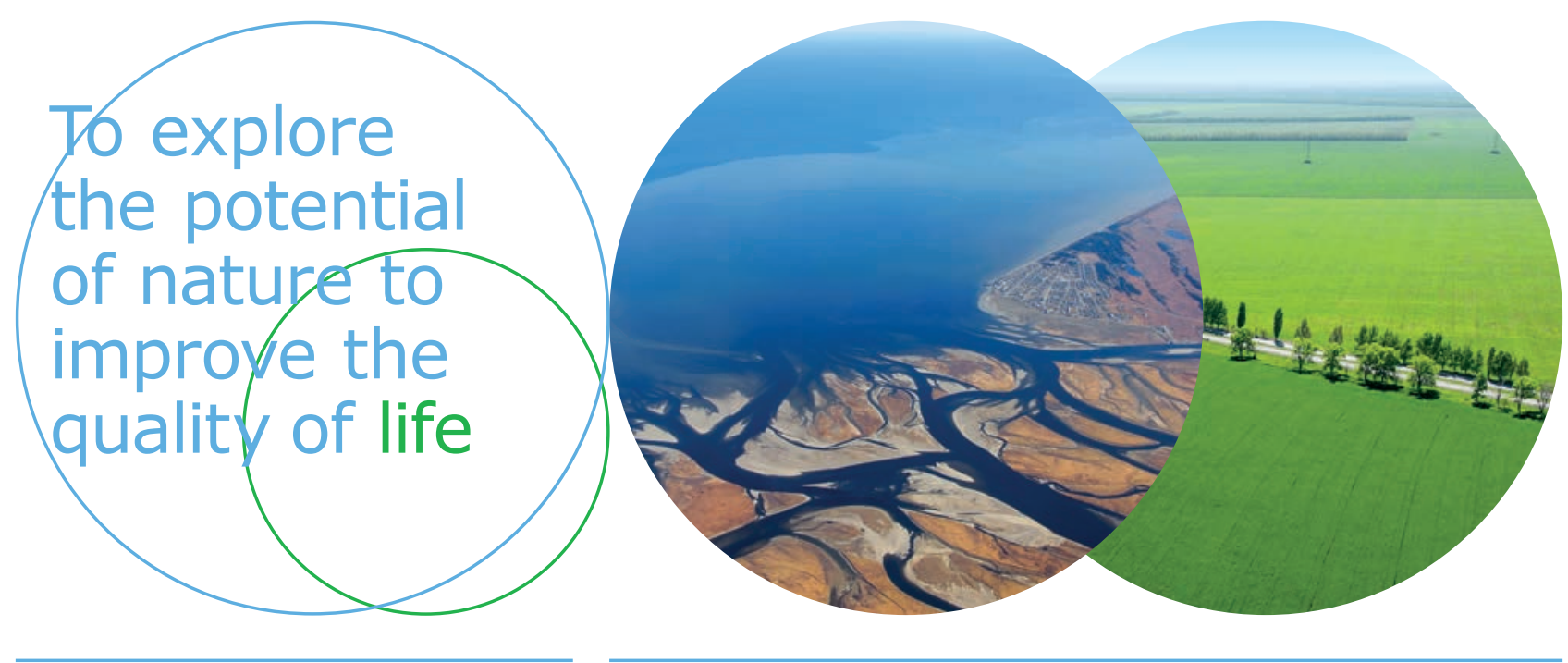

Wageningen Environmental Research Postbus 47

$6700 \mathrm{AB}$ Wageningen

T 317480700

www.wur.nl/environmental-research

Rapport 3012

ISSN 1566-7197
De missie van Wageningen University \& Research is 'To explore the potential of nature to improve the quality of life'. Binnen Wageningen University \& Research bundelen Wageningen University en gespecialiseerde onderzoeksinstituten van Stichting Wageningen Research hun krachten om bij te dragen aan de oplossing van belangrijke vragen in het domein van gezonde voeding en leefomgeving. Met ongeveer 30 vestigingen, 5.000 medewerkers en 12.000 studenten behoort Wageningen University \& Research wereldwijd tot de aansprekende kennisinstellingen binnen haar domein. De integrale benadering van de vraagstukken en de samenwerking tussen verschillende disciplines vormen het hart van de unieke Wageningen aanpak. 